\title{
Inhibition of the Rumen Ciliate Entodinium caudatum by Antibiotics
}

\author{
Tansol Park ${ }^{1}$, Tea Meulia ${ }^{2}$, Jeffrey L. Firkins ${ }^{1}$ and Zhongtang Yu ${ }^{1 *}$ \\ ${ }^{1}$ Department of Animal Sciences, The Ohio State University, Columbus, $\mathrm{OH}$, United States, ${ }^{2}$ Molecular and Cellular Imaging \\ Center, Ohio Agricultural Research and Development Center and the Department of Plant Pathology, Ohio State University, \\ Wooster, $\mathrm{OH}$, United States
}

OPEN ACCESS

Edited by:

Diego P. Morgavi,

INRA Centre Auvergne - Rhône-Alpes,

France

Reviewed by:

Gabriel De La Fuente,

University of Lleida, Spain

Charles James Newbold,

Aberystwyth University,

United Kingdom

*Correspondence:

Zhongtang $Y u$

yu.226@osu.edu

Specialty section:

This article was submitted to

Microbial Symbioses,

a section of the journal

Frontiers in Microbiology

Received: 14 January 2017

Accepted: 12 June 2017

Published: 28 June 2017

Citation:

Park T, Meulia T, Firkins JL and Yu Z (2017) Inhibition of the Rumen Ciliate Entodinium caudatum by Antibiotics.

Front. Microbiol. 8:1189.

doi: 10.3389/fmicb.2017.01189
Axenic cultures of free-living aerobic ciliates, such as Tetrahymena thermophila and Paramecium aurelia, have been established and routinely used in laboratory research, greatly facilitating, or enabling characterization of their metabolism, physiology, and ecology. Ruminal protozoa are anaerobic ciliates, and they play important roles in feed digestion and fermentation. Although, repeatedly attempted, no laboratory-maintainable axenic culture of ruminal ciliates has been established. When axenic ciliate cultures are developed, antibiotics are required to eliminate the accompanying bacteria. Ruminal ciliates gradually lose viability upon antibiotic treatments, and the resultant axenic cultures can only last for short periods of time. The objective of this study was to evaluate eight antibiotics that have been evaluated in developing axenic cultures of ruminal ciliates, for their toxicity to Entodinium caudatum, which is the most predominant ruminal ciliate species. Scanning and transmission electron microscopy (TEM) showed that the antibiotics damaged both the cell surface and nuclei of E. caudatum and increased accumulation of intracellular glycogen. Combinations of the three least toxic antibiotics failed to eliminate the bacteria that are present in the E. caudatum culture. The combination of ampicillin, carbenicillin, streptomycin, and oxytetracycline was able to eliminate all the bacteria, but the resultant axenic E. caudatum culture gradually lost viability. Adding the bacterial fraction (live) separated from an untreated $E$. caudatum culture reversed the viability decline and recovered the growth of the treated $E$. caudatum culture, whereas feeding nine strains of live bacteria isolated from E. caudatum cells, either individually or in combination, could not. Nutritional and metabolic dependence on its associated bacteria, accompanied with direct and indirect inhibition by antibiotics, makes it difficult to establish an axenic culture of E. caudatum. Monoxenic or polyxenic cultures of $E$. caudatum could be developed if the essential symbiotic partner(s) can be identified.

Keywords: antibiotics, associated bacteria, axenic culture, Entodinium, ruminal protozoa

\section{INTRODUCTION}

Pure cultures of microorganisms had been a gold standard for microbiological experimentation until the end of the twentieth century, and most of the current knowledge on microbial metabolism, physiology, and ecology were obtained from studies using pure cultures of microorganisms (Schmidt, 2006). Although, the contemporary $\sim$ omic technologies allow direct studies of microbes, pure cultures still enable, or at least facilitate, elucidation of the physiology and 
metabolism expressed in the niche of individual microbes. Therefore, the initial effort in traditional microbiological research is to obtain pure cultures for detailed studies. Moreover, pure cultures are needed to utilize the unique metabolic capacities of some microbes to produce compounds and products of commercial interest. In protozoology research, the early effort was made and succeeded in establishing axenic cultures of model protozoan species (Lwoff, 1923; Biagini et al., 1998). Because of their large cell sizes, protozoa can be isolated and maintained as cultures of single protozoal species by picking individual protozoal cells under a microscope. These singlespecies protozoal cultures contain bacteria and archaea, and combinations of antibiotics are used to kill off the contaminating bacteria and archaea. Tetrahymena thermophila, which is an aerobic free-living ciliate residing in freshwater and used as a model species of ciliates, was the first axenically grown protozoal species (Lwoff, 1923). Axenic cultures of Paramecium aurelia, another free-living freshwater model ciliate species, was also established (Soldo, 1963). Then, axenic cultures of several parasitic ciliates, including Hexamita (Biagini et al., 1998) and Giardia ardeae (Erlandsen et al., 1990) and free-living marine ciliates (Yamada et al., 1997; Cho et al., 2002; Wilkens and Maas, 2012) were successfully established. The axenic cultures of these ciliated can be maintained in laboratory, and they have greatly facilitated or enabled characterization of their metabolism, physiology, and ecology. Although physical separation using migration, filtration, and centrifugation is helpful in establishing axenic cultures of protozoa, antibiotics (often a combination of several antibiotics) are indispensable to eliminate the bacteria and archaea that are present in the monocultures of protozoa (Allen and Nerad, 1978). Antibiotics are also added to media to decontaminate axenic cultures of protozoa and mammalian cells that are contaminated with microbes. The growth of the aforementioned axenic protozoa can be maintained by providing growth factors in the media. For T. thermophila, media and axenic stock cultures are commercially available, which has greatly facilitated and enabled studies of this species.

Ruminal protozoa comprise anaerobic ciliates, and they have been estimated to provide up to $50 \%$ of the rumen microbial biomass (Newbold et al., 2015). Ruminal ciliates contribute to feed degradation but also lower nitrogen utilization efficiency and increase methane production (Firkins et al., 2007; Newbold et al., 2015). Sitting at the top of the food chain in the rumen, ruminal ciliates prey on other microbes, primarily ruminal bacteria (Williams and Coleman, 1992). Through digesting the engulfed preys, these ciliates meet their nutrient requirements for growth factors, such as amino acids, nucleic acid, and vitamins, and other nutrients (Bonhomme, 1990). Some bacteria and archaea are also shown to be associated with ruminal ciliates (Lloyd et al., 1996), but it remains unknown if these associated prokaryotes (endo-or ecto-symbiotic) provide any growth factors that are absolutely needed for the survival of ruminal protozoa. To better understand ruminal ciliates, many researchers have attempted to develop axenic cultures of ruminal ciliate protozoal species, especially E. caudatum, the most dominant ruminal ciliate species in ruminant animals (Sylvester et al., 2005). However, none of the attempts has succeeded in developing any axenic culture of ruminal ciliates in the laboratory that could be maintained for long-term use (Coleman, 1962; Hino and Kametaka, 1977; Bonhomme et al., 1982a,b). We hypothesize that the failure to establish and maintain axenic cultures of ruminal ciliates is probably attributable to the toxicity of antibiotics to ruminal protozoa. Toxicity of antibiotics to eukaryotes has been discussed for a long time, mainly in the context of clinical applications such as side effects or antibiotic resistance and, or free-living unicellular as model organisms (Eustice and Wilhelm, 1984; Van Bambeke et al., 2003; Barnhill et al., 2012). However, few studies in the literature have systematically addressed potential toxicity of antibiotics to ruminal ciliates (Varadyova et al., 2001). The objective of the present study was to investigate possible toxicity of eight antibiotics, which have been used in attempts to make axenic cultures of various types of ciliates including E. caudatum. Both scanning electron microscopy (SEM) and transmission electron microscopy (TEM) were used to reveal the morphological changes of E. caudatum cells caused by the antibiotics.

\section{MATERIALS AND METHODS}

\section{E. caudatum Culture}

The E. caudatum culture used in the present study was initially established from a single cell isolated from the rumen of a gerenuk by Dehority (2010). This culture contained only E. caudatum as ruminal ciliates, but it also contained bacteria and probably archaea. This E. caudatum culture has been maintained by frequent transfers (50\% inoculum) every 34 days into autoclaved SP medium (Dehority, 1998), and it is also cryopreserved at $-80^{\circ} \mathrm{C}$ in the presence of $4 \%(\mathrm{v} / \mathrm{v})$ dimethylsulphoxide as the cryoprotectant (Nsabimana et al., 2003). A protozoan feed consisting of ground wheat grain and alfalfa and grass hays was fed daily as recommend by Dehority (2010). The volume of the culture was increased by adding fresh SP medium, which contained (per liter) $5 \mathrm{~g}$ of $\mathrm{K}_{2} \mathrm{HPO}_{4}, 4 \mathrm{~g}$ of $\mathrm{KH}_{2} \mathrm{PO}_{4}, 1 \mathrm{~g}$ of $\mathrm{NaCl}, 0.053 \mathrm{~g}$ of $\mathrm{CaCl}_{2} \cdot 2 \mathrm{H}_{2} \mathrm{O}, 0.0385 \mathrm{~g}$ of $\mathrm{MgSO}_{4}$, $6 \mathrm{~g}$ of $\mathrm{NaHCO}_{3}, 10 \%(\mathrm{v} / \mathrm{v})$ of clarified rumen fluid, $0.67 \%(\mathrm{v} / \mathrm{v})$ of $3 \%$ cysteine- $\mathrm{HCl}$ solution to the culture to prepare adequate E. caudatum cells needed for the large number of antibiotic treatments.

\section{Antibiotics}

Eight different antibiotics (Table 1) were tested for their efficacy to test their toxicity to E. caudatum cells and to eliminate the bacteria present in the E. caudatum culture. A stock solution of each antibiotic was prepared by dissolving in distilled water (except for chloramphenicol, which was dissolved in ethanol because it is insoluble in water) and filter-sterilized using Minisart syringe filters (pore size, $0.22 \mu \mathrm{m}$; Sartorius, Germany). The detailed information on concentrations used, target bacteria, and mechanism and mode of action is shown in Table 1. Dosages of each antibiotic were selected based on both references listed in Table 2 and the results of a preliminary experiment using the same E. caudatum culture. 
TABLE 1 | List of all antibiotics used in this study*

\begin{tabular}{|c|c|c|c|c|c|}
\hline Antibiotic & Stock solution & Final Conc. & Main mechanism of action & $\begin{array}{l}\text { Antimicrobial } \\
\text { spectrum }\end{array}$ & $\begin{array}{l}\text { Bactericidal/ } \\
\text { Bacteriostatic }\end{array}$ \\
\hline Ampicillin (Sigma, A9518) & $50 \mathrm{mg} / \mathrm{ml}$ in $\mathrm{H}_{2} \mathrm{O}$ & $0.1-2 \mathrm{mg} / \mathrm{ml}$ & Cell wall & $\operatorname{Gram}(+),(-)$ & Bactericidal \\
\hline Streptomycin (Sigma, S9137) & $25 \mathrm{mg} / \mathrm{ml}$ in $\mathrm{H}_{2} \mathrm{O}$ & $0.1-2 \mathrm{mg} / \mathrm{ml}$ & $\begin{array}{l}\text { Aminoglycoside, } 30 \text { S protein } \\
\text { synthesis }\end{array}$ & Gram (+), (-) & Bactericidal \\
\hline Carbenicillin (Sigma, C3416) & $50 \mathrm{mg} / \mathrm{ml}$ in $\mathrm{H}_{2} \mathrm{O}$ & $0.1-2 \mathrm{mg} / \mathrm{ml}$ & Cell wall & $\operatorname{Gram}(+),(-)$ & Bactericidal \\
\hline Tetracycline (Sigma, T3383) & $50 \mathrm{mg} / \mathrm{ml}$ in $\mathrm{H}_{2} \mathrm{O}$ & $0.03-0.3 \mathrm{mg} / \mathrm{ml}$ & 30 S protein synthesis & $\operatorname{Gram}(+),(-)$ & Bacteriostatic \\
\hline Neomycin (Sigma, N6910) & $50 \mathrm{mg} / \mathrm{ml}$ in $\mathrm{H}_{2} \mathrm{O}$ & $0.1-1 \mathrm{mg} / \mathrm{ml}$ & $\begin{array}{l}\text { Aminoglycoside, } 305 \text { protein } \\
\text { synthesis }\end{array}$ & Gram $(+),(-)$ & Bactericidal \\
\hline Bacitracin (Sigma, B5150) & $50 \mathrm{mg} / \mathrm{ml}$ in $1 \mathrm{~N} \mathrm{HCl}$ & $0.05-1 \mathrm{mg} / \mathrm{ml}$ & Cell wall & Gram (+) & Bactericidal \\
\hline Normocin ${ }^{\mathrm{TM}}$ (InvivoGen) & Commercial & $0.05-0.5 \mathrm{mg} / \mathrm{ml}$ & $\begin{array}{l}50 S \text { protein synthesis + DNA } \\
\text { synthesis + disrupting ionic exchange } \\
\text { through cell membrane (yeast \& fungi) }\end{array}$ & $\begin{array}{l}\text { Gram }(+),(-) \\
\text { Fungi }\end{array}$ & Bactericidal \\
\hline Chloramphenicol (Sigma, C0378) & $50 \mathrm{mg} / \mathrm{ml}$ in ethanol & $0.005-0.05 \mathrm{mg} / \mathrm{ml}$ & $50 S$ protein synthesis & Gram (+), (-) & Bacteriostatic \\
\hline
\end{tabular}

*Based on Gottlieb and Shaw, 1967; Foster, 1983; Moazed and Noller, 1987; Ocampo et al., 2014.

\section{Experiment 1: Growth Inhibition of E. caudatum and Its Associated Prokaryotes by Individual Antibiotics Culturing}

The E. caudatum culture was filtered and then washed three times as described previously using a filtration apparatus (Williams and Yarlett, 1982; Williams and Coleman, 1992) to remove most of the contaminating prokaryotes. Briefly, the E. caudatum culture was filtered (with washing) sequentially through 50 - and then $25-\mu \mathrm{m}$ nylon filter membranes (Sefar Filtration Inc., New York, USA) to remove the feed particles and then through a 10$\mu \mathrm{m}$ nylon filter membrane that retains the E. caudatum cells but allows the free-living prokaryotes to pass through. Prewarmed $\left(\right.$ at $39^{\circ} \mathrm{C}$ ) anaerobic Simplex buffer (modified from Williams and Coleman, 1992), which was prepared anaerobically by adding $0.02 \%(\mathrm{w} / \mathrm{v}$ ) of L-cysteine-hydrochloride and sparging with $\mathrm{CO}_{2}$ overnight, was used to wash the E. caudatum cells retained on the $10-\mu \mathrm{m}$ nylon filter membrane. To protect the E. caudatum cells from exposure to air during the filtration, four continuous fluxes of $\mathrm{CO}_{2}$ were directed above the filter membrane through ports pointing down on the inside of the filtration apparatus (Williams and Yarlett, 1982). The washed E. caudatum cells were collected into pre-warmed $\left(39^{\circ} \mathrm{C}\right)$ Simplex buffer of the same volume as the original culture. Suspensions of the washed E. caudatum cells $(0.5 \mathrm{ml}$ each) were inoculated into $4.5 \mathrm{ml}$ of anaerobic SP medium (Dehority, 1998). Approximately $0.01 \mathrm{~g}$ of the protozoan feed was added to each tube. The cell concentration of the E. caudatum cell suspension was determined by microscopic counting (Dehority, 1993). Briefly, a small aliquot of the cell suspension was mixed with an equal volume each of 50\% formalin and $30 \%$ glycerol. The fixed E. caudatum cells were loaded onto a SedgewickRafter counting chamber (Thomas Scientific, no. 9851 C20, Swedesboro, NJ). The E. caudatum cells within 50 random $0.25 \mathrm{~mm}^{2}$ grids in the microscope eyepiece were counted twice under $100 \mathrm{x}$ total magnification. To aid microscopic counting, the fixed E. caudatum cells were stained with brilliant green dye.
Growth inhibition and toxicity of each antibiotic were evaluated using the suspension of the washed E. caudatum cells as the inoculum. Briefly, each of the selected antibiotics was added to the E. caudatum cultures at the pre-set final concentrations (Table 1). After flushing the headspace with filter-sterilized $\mathrm{CO}_{2}$, the culture tubes were sealed with a rubber stopper and incubated at $39^{\circ} \mathrm{C}$ at a $10^{\circ}$ angle (Dehority, 1998). Each E. caudatum culture was subsampled $(0.5 \mathrm{ml}$ each time) at 24,48 , and $72 \mathrm{~h}$, and the concentration of E. caudatum was determined using microscopic counting as described above. The growth of associated prokaryotes was estimated by optical density (OD) at $600 \mathrm{~nm}$ using a Spectronic 20D+ (Spectronic Instruments, USA) before each subsampling. Sterile SP medium was used as the blank to zero the spectrophotometer (the cells of E. caudatum settle to the bottom of the cultures and contribute little to culture OD).

\section{Electron Microscopy}

E. caudatum cells were collected from all cultures (both the antibiotics-treated and the controls receiving no antibiotics) by centrifugation at $500 \times \mathrm{g}$ for $5 \mathrm{~min}$. The cells were fixed in a fixative buffer, which contains $0.1 \mathrm{M}$ potassium phosphate $(\mathrm{pH}$ 7.2 ), $3 \%$ glutaraldehyde, and $2 \%$ paraformaldehyde, for $2 \mathrm{~h}$ at room temperature and then stored at $4{ }^{\circ} \mathrm{C}$ overnight. Samples were then divided into two aliquots with one for scanning and the other for TEM processing.

For SEM, cells were rinsed with a potassium phosphate buffer $(\mathrm{PB}, 0.1 \mathrm{M}, \mathrm{pH}$ 7.2) thrice, $10 \mathrm{~min}$ each. After each rinse and after each of the following steps, the cells were collected by centrifugation as mentioned above. Cells were then postfixed in $1 \%$ osmium tetroxide and $1 \%$ uranyl acetate in $\mathrm{PB}$ for $1 \mathrm{~h}$, washed twice with $\mathrm{PB}$, and then dehydrated through sequential washes in $50,75,95 \%$ ethanol twice (15 min each at each ethanol concentration) and then in $100 \%$ ethanol twice (15 min each). Dehydrated cells were transferred to $100 \%$ hexamethyldisilazane (Sigma-Aldrich Ltd, St-Louis, USA). After two changes of the hexamethyldisilazane, the cells air-dried a chemical hood. Finally, the cells were mounted onto a specimen holder and subsequently spatter coated with platinum and viewed 
TABLE 2 | Literature review about previous research on establishing axenic culture of protozoa and algae.

\begin{tabular}{|c|c|c|c|c|}
\hline Host microbes & Bacterial contamination & Protozoal growth & Combination of antibiotics & References \\
\hline E. caudatum & $\begin{array}{l}\text { Low bacterial contamination } \\
\left(10^{3}-10^{4} \text { bacteria/ml) }\right.\end{array}$ & $\begin{array}{l}\text { Entodinia could be } \\
\text { maintained alive for only 3-4 } \\
\text { days }\end{array}$ & $\begin{array}{l}\text { Penicillin }(1,400 \mathrm{U} / \mathrm{ml}) \\
\text { Streptomycin sulfate }(570 \mu \mathrm{g} / \mathrm{ml}) \\
\text { Dihydrostreptomycin }(570 \mu \mathrm{g} / \mathrm{ml}) \\
\text { Neomycin sulfate }(570 \mu \mathrm{g} / \mathrm{ml})\end{array}$ & Coleman, 1962 \\
\hline E. caudatum & $\begin{array}{l}\text { Enabled inhibition of growth } \\
\text { completely; no growth was seen } \\
\text { up to } 10 \text { days }\end{array}$ & $\begin{array}{l}\text { These axenic protozoa } \\
\text { could be kept alive in the } \\
\text { presence of dead bacterial } \\
\text { cells for up to } 3 \text { weeks, but } \\
\text { their growth was extremely } \\
\text { slow }\end{array}$ & $\begin{array}{l}\text { Carbenicillin }(500 \mu \mathrm{g} / \mathrm{ml}) \\
\text { Aminobenzylpenicillin }(500 \mu \mathrm{g} / \mathrm{ml}) \\
\text { Cephaloridine }(500 \mu \mathrm{g} / \mathrm{ml}) \\
\text { Chloramphenicol }(100 \mu \mathrm{g} / \mathrm{ml}) \\
\text { Leucomycin }(100 \mu \mathrm{g} / \mathrm{ml})\end{array}$ & Hino and Kametaka, 1977 \\
\hline $\begin{array}{l}\text { Cellulolytic Flagellate } \\
\text { Trichomitopsis termopsidis } \\
\text { (from hindgut of termite) }\end{array}$ & $\begin{array}{l}\text { Axenic status after } 2 \text { passages } \\
\text { (in } 30 \text { days) }\end{array}$ & $\begin{array}{l}\text { T. termopsidis did multiply } \\
\text { w/10\% (v/v) autoclaved } \\
\text { rumen fluid + cellulose }+ \\
\text { GSH + serum, and } \\
\text { antibiotics }\end{array}$ & $\begin{array}{l}\text { Penicillin }(1,000 \mathrm{U} / \mathrm{ml})=600 \mu \mathrm{g} / \mathrm{ml} \\
\text { Streptomycin }(1 \mathrm{mg} / \mathrm{ml})\end{array}$ & Yamin, 1978 \\
\hline Paramecium spp. & $\begin{array}{l}\text { Axenic culture was maintained } \\
\text { (Migration + adaptation medium } \\
\text { plus antibiotics) }\end{array}$ & $\begin{array}{l}\text { The ciliates can be maintain } \\
\text { in the growth medium }\end{array}$ & $\begin{array}{l}\text { Penicillin }(100 \mathrm{U} / \mathrm{ml}) \text {, Streptomycin } \\
(100 \mu \mathrm{g} / \mathrm{ml}) \text {, and fungizone } \\
(0.25 \mu \mathrm{g} / \mathrm{ml})\end{array}$ & Allen and Nerad, 1978 \\
\hline E. caudatum & $\begin{array}{l}\text { Low bacterial contamination } \\
\text { levels }\end{array}$ & $\begin{array}{l}\text { Cell-free extract of mixed } \\
\text { rumen bacteria } \\
\text { adsorbed on activated } \\
\text { charcoal was relieved the } \\
\text { stress of low bacterial } \\
\text { contamination }\end{array}$ & $\begin{array}{l}50 \mu \mathrm{g} / \mathrm{ml} \text { each of streptomycin, } \\
\text { penicillin and chloramphenicol and } \\
\text { sulphadrug }\end{array}$ & $\begin{array}{l}\text { Onodera and Henderson, } \\
1980\end{array}$ \\
\hline Giardia ardeae & $\begin{array}{l}\text { Axenic culture } \\
\text { (confirmed through SEM) }\end{array}$ & $\begin{array}{l}\text { Established in axenic culture } \\
\text { using the TYI-S-33 medium }\end{array}$ & $\begin{array}{l}\text { Bacitracin }(50 \mu \mathrm{g} / \mathrm{ml}) \\
\text { Gentamicin }(100 \mu \mathrm{g} / \mathrm{ml}) \\
\text { Penicillin }(25 \mathrm{U} / \mathrm{ml}) \\
\text { Streptomycin }(25 \mu \mathrm{g} / \mathrm{ml}) \\
\text { Amphotericin B }(0.06 \mu \mathrm{g} / \mathrm{ml})\end{array}$ & Erlandsen et al., 1990 \\
\hline E. exiguum \& E. caudatum & $\begin{array}{l}\text { The antibiotic solution effectively } \\
\text { killed more than } 99 \% \text { of the } \\
\text { bacteria in } 4 \mathrm{~h} \text { (bacterial counts } \\
\text { using MPN) }\end{array}$ & $\begin{array}{l}\text { Much better growth with live } \\
\text { bacteria }\end{array}$ & $\begin{array}{l}\text { Approximately, } \\
\text { Penicillin }(1250 \mathrm{U} / \mathrm{ml}) \\
\text { Streptomycin }(81.25 \mathrm{U} / \mathrm{ml})\end{array}$ & $\begin{array}{l}\text { Fondevila and Dehority, } \\
2001\end{array}$ \\
\hline $\begin{array}{l}\text { Marine microalga } \\
\text { Isochrysis galbana }\end{array}$ & $\begin{array}{l}\text { Removal of bacteria was } \\
\text { accomplished using a mixture of } \\
5 \text { antibiotics (axenic after } 3 \text { days } \\
\text { incubation) }\end{array}$ & $\begin{array}{l}\text { Similar growth with } \\
\text { reference culture }\end{array}$ & $\begin{array}{l}\text { Ampicillin }(500 \mu \mathrm{g} / \mathrm{ml}) \\
\text { Gentamycin }(100 \mu \mathrm{g} / \mathrm{ml}) \\
\text { Kanamycin }(200 \mu \mathrm{g} / \mathrm{ml}) \\
\text { Neomycin }(1 \mathrm{mg} / \mathrm{ml}) \\
\text { Streptomycin }(100 \mu \mathrm{g} / \mathrm{ml})\end{array}$ & Cho et al., 2002 \\
\hline $\begin{array}{l}\text { Rumen ciliates: } \\
\text { Polyplastron } \\
\text { multivesiculatum, Isotricha } \\
\text { intestinalis, and } \\
\text { Ophryoscolex purkynjei }\end{array}$ & $\begin{array}{l}\text { No PCR amplification of bacterial } \\
\text { or archaeal } 16 \mathrm{~S} \text { rRNA gene from } \\
\text { the culture supernatant } \\
\text { ( } 48 \mathrm{~h} \text { incubation) }\end{array}$ & $\begin{array}{l}\text { Over } 90 \% \text { was maintained } \\
\text { after } 48 \mathrm{~h} \text { with antibiotics } \\
\text { mixture }\end{array}$ & $\begin{array}{l}\text { Penicillin G potassium }(100 \mu \mathrm{g} / \mathrm{ml}) \\
\text { Streptomycin sulfate }(100 \mu \mathrm{g} / \mathrm{ml}) \\
\text { Kanamycin sulfate }(100 \mu \mathrm{g} / \mathrm{ml}) \\
\text { 5-Fluorocytosine }(50 \mu \mathrm{g} / \mathrm{ml}) \\
\text { Chloramphenicol }(3.2 \mu \mathrm{g} / \mathrm{ml})\end{array}$ & Irbis and Ushida, 2004 \\
\hline Tetrahymena spp. & Axenic culture & - & $\begin{array}{l}\text { Neomycin }(100 \mu \mathrm{g} / \mathrm{ml}) \text {, } \\
\text { Kanamycin }(100 \mu \mathrm{g} / \mathrm{ml}) \text {, } \\
\text { Tetracycline }(100 \mu \mathrm{g} / \mathrm{ml}) \\
\text { Normocin }^{\mathrm{TM}}(2 \mu \mathrm{l} / \mathrm{ml}) \\
\text { Normocin }^{\mathrm{TM}}, \text { Penicillin }(250 \mu \mathrm{g} / \mathrm{ml}) \text {, } \\
\text { Streptomycin }\left(250 \mu \mathrm{g} / \mathrm{ml}^{\mathrm{T}}\right) \\
\text { Three-fold of Normocin }\end{array}$ & Cassidy-Hanley, 2012 \\
\hline
\end{tabular}


TABLE 3 | E. caudatum data (\% of that of the control) in the presence of different antibiotics ( $\mathrm{mg} / \mathrm{ml}$ ).

\begin{tabular}{|c|c|c|c|c|c|c|c|}
\hline \multirow[t]{2}{*}{ Cell counts } & \multicolumn{3}{|c|}{ Incubation times (h) } & \multirow[t]{2}{*}{ SEM } & \multicolumn{3}{|c|}{ Effects } \\
\hline & 24 & 48 & 72 & & A & Time & $A^{\star} T$ \\
\hline Control & $12080^{a}$ & $19395^{a}$ & 19999a & 1440 & & & \\
\hline \multicolumn{8}{|l|}{ AMPICILLIN } \\
\hline 0.1 & 0.83 & $0.47^{\mathrm{ab}}$ & $0.52^{a b}$ & 0.12 & $<0.0001$ & $<0.0001$ & 0.0066 \\
\hline 0.5 & 0.84 & $0.01^{b}$ & $0.01^{b}$ & 0.14 & & & \\
\hline 1 & 0.83 & $0.43^{a b}$ & $0^{b}$ & 0.13 & & & \\
\hline 2 & 0.85 & $0.63^{a}$ & $0.47^{\mathrm{ab}}$ & 0.06 & & & \\
\hline Contrast & - & $Q^{\star \star \star}$ & $L^{\star}, Q^{\star \star \star}$ & & & & \\
\hline \multicolumn{8}{|c|}{ STREPTOMYCIN } \\
\hline 0.1 & 0.82 & $1.03^{a}$ & $1.11^{\mathrm{a}}$ & 0.07 & $<0.0001$ & 0.257 & 0.0031 \\
\hline 0.5 & 0.95 & $0.89^{a}$ & $0.98 a^{b}$ & 0.03 & & & \\
\hline 1 & 0.69 & $0.55^{\mathrm{b}}$ & $0.76^{b}$ & 0.05 & & & \\
\hline 2 & 0.88 & $0.49^{b}$ & $0.42^{C}$ & 0.08 & & & \\
\hline Contrast & - & $L^{\star \star \star}, Q^{\star}$ & $L^{* \star \star}$ & & & & \\
\hline \multicolumn{8}{|c|}{ CARBENICILLIN } \\
\hline 0.1 & 0.83 & $0.64^{b}$ & $0.85^{a}$ & 0.04 & $<0.0001$ & $<0.0001$ & 0.0004 \\
\hline 0.5 & 0.87 & $0.45^{\mathrm{b}}$ & $0.43^{b}$ & 0.07 & & & \\
\hline 1 & 0.93 & $0.56^{b}$ & $0.44^{b}$ & 0.08 & & & \\
\hline 2 & 0.78 & $0.49^{b}$ & $0.28^{b}$ & 0.08 & & & \\
\hline Contrast & - & $L^{\star \star \star}, Q^{\star \star \star}$ & $L^{\star \star \star}, Q^{\star \star \star}$ & & & & \\
\hline \multicolumn{8}{|c|}{ TETRACYCLINE } \\
\hline 0.03 & 0.94 & $0.58^{b}$ & $0.2^{b}$ & 0.11 & $<0.0001$ & $<0.0001$ & 0.0001 \\
\hline 0.05 & 0.87 & $0.49^{b c}$ & $0.23^{b}$ & 0.1 & & & \\
\hline 0.1 & 0.88 & $0.55^{\mathrm{b}}$ & $0.17^{\mathrm{b}}$ & 0.11 & & & \\
\hline 0.3 & 0.81 & $0.24^{\mathrm{C}}$ & $0.03^{b}$ & 0.12 & & & \\
\hline Contrast & - & $L^{\star \star \star}, Q^{\star \star}$ & $L^{* \star *}, Q^{\star * \star}$ & & & & \\
\hline \multicolumn{8}{|l|}{ NEOMYCIN } \\
\hline 0.1 & 0.85 & $0.75^{\mathrm{b}}$ & $0.96^{a}$ & 0.04 & $<0.0001$ & $<0.0001$ & 0.0011 \\
\hline 0.3 & 0.84 & $0.53^{b c}$ & $0.51^{b}$ & 0.06 & & & \\
\hline 0.6 & 0.76 & $0.51^{\mathrm{C}}$ & $0.37^{b}$ & 0.06 & & & \\
\hline 1 & 0.74 & $0.42^{\mathrm{C}}$ & $0.33^{b}$ & 0.07 & & & \\
\hline Contrast & $L^{*}$ & $L^{\star \star \star}, Q^{\star \star \star}$ & $L^{\star \star \star}, Q^{\star \star \star}$ & & & & \\
\hline \multicolumn{8}{|l|}{ BACITRACIN } \\
\hline 0.05 & $0.89^{a b}$ & $0.72^{\mathrm{ab}}$ & $0.56^{b}$ & 0.07 & $<0.0001$ & $<0.0001$ & 0.0514 \\
\hline 0.1 & $0.93^{a b}$ & $0.58^{\mathrm{b}}$ & $0.5^{\mathrm{b}}$ & 0.08 & & & \\
\hline 0.5 & $0.71^{a b}$ & $0.54^{b}$ & $0.4^{b}$ & 0.05 & & & \\
\hline 1 & $0.49^{b}$ & $0.07^{c}$ & $0.01^{\mathrm{C}}$ & 0.08 & & & \\
\hline Contrast & $L^{* * *}$ & $L^{\star \star \star}$ & $L^{* * *}$ & & & & \\
\hline \multicolumn{8}{|c|}{ NORMOCIN TM } \\
\hline 0.05 & $0.89^{a b}$ & $0.65^{\mathrm{b}}$ & $0.56^{b}$ & 0.06 & $<0.0001$ & $<0.0001$ & 0.2012 \\
\hline 0.1 & $0.69^{a b}$ & $0.47^{\mathrm{bc}}$ & $0.57^{\mathrm{b}}$ & 0.04 & & & \\
\hline 0.3 & $0.69^{a b}$ & $0.39^{b c}$ & $0.31^{\mathrm{C}}$ & 0.07 & & & \\
\hline 0.5 & $0.5^{b}$ & $0.18^{C}$ & $0.1^{c}$ & 0.08 & & & \\
\hline Contrast & $L^{\star \star \star}$ & $L^{\star \star \star}, Q^{\star \star}$ & $L^{\star \star \star}, Q^{\star \star}$ & & & & \\
\hline \multicolumn{8}{|c|}{ CHLORAMPHENICOL } \\
\hline 0.005 & $0.82^{a}$ & $0.11^{b}$ & $0.08^{b}$ & 0.13 & $<0.0001$ & $<0.0001$ & $<0.0001$ \\
\hline 0.01 & $0.76^{a b}$ & $0^{\mathrm{b}}$ & $0^{\mathrm{b}}$ & 0.13 & & & \\
\hline 0.03 & $0.71^{a b}$ & $0^{b}$ & $0^{b}$ & 0.12 & & & \\
\hline 0.05 & $0.39^{b}$ & $0^{b}$ & $0^{b}$ & 0.07 & & & \\
\hline Contrast & $L^{* \star \star}$ & $L^{\star \star \star}, Q^{\star \star \star}$ & $L^{\star \star \star}, Q^{\star \star \star}$ & & & & \\
\hline
\end{tabular}

The final concentrations of antibiotics were in $\mathrm{mg} / \mathrm{ml}$. Different superscripts $(a-c)$ in the same column denote significant difference $(P<0.05)$ in the proportion of protozoa cell counts

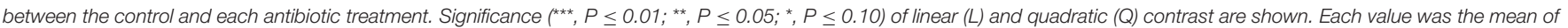
three replicates. A, antibiotics; $T$, incubation time. 
TABLE 4 | Correlation between protozoal cell counts and optical density (OD) of antibiotics-treated $E$. caudatum cultures $(n=3)$.

\begin{tabular}{lcc}
\hline Antibiotics & Pearson & $\boldsymbol{P}$-value \\
\hline Overall & 0.14 & 0.0167 \\
Ampicillin & 0.30 & 0.0421 \\
Streptomycin & -0.11 & 0.4752 \\
Carbenicillin & 0.66 & $<0.0001$ \\
Tetracycline & 0.62 & $<0.0001$ \\
Neomycin & 0.64 & $<0.0001$ \\
Bacitracin & -0.51 & 0.0003 \\
Normocin & 0.57 & $<0.0001$ \\
Chloramphenicol & 0.80 & $<0.0001$ \\
\hline
\end{tabular}

on a Hitachi S-4700 (Hitachi America, Ltd.) scanning electron microscope.

For TEM, fixed cells were collected by low-speed centrifugation at $500 \times \mathrm{g}$ for $5 \mathrm{~min}$ and embedded in $0.8 \%$ low melting agarose (Thermofisher Scientific Company, Waltham, MA). The cells/agarose blocks were washed thrice with $\mathrm{PB}$ and post-fixed with $1 \%$ osmium tetroxide and $1 \%$ uranyl acetate in $\mathrm{PB}$ at room temperature for $1 \mathrm{~h}$. The cells were then dehydrated through a graded ethanol series $(50,75$, 95, and 100\%) as described above for SEM, resin-infiltrated using a propylene oxide-resin series, and then embedded in EM Bed-812 resin (Electron Microscopy Sciences, Hartfield, PA). Ultrathin-sections $(60-70 \mathrm{~nm})$ were prepared using a Leica EM UC6 ultra-microtome. Sections from five separate blocks were obtained for each sample. After staining with 3\% aqueous uranyl acetate for $20 \mathrm{~min}$, followed by Reynolds' lead citrate for $10 \mathrm{~min}$ (Reynolds, 1963), all the sections were viewed using a Hitachi H-7500 transmission electron microscope (Hitachi America, Ltd.). Images were acquired using an Optronics QuantiFire ${ }^{\circledR}$ S99835 (SIA) digital camera. Size (area) of the glycogen granules of the control and antibiotics-treated cell was measured using ImageJ (Abràmoff et al., 2004).

\section{Experiment 2: Preparation of a Temporarily Axenic Culture of $E$. caudatum and Its Growth Recovery}

Three of the antibiotics tested above (carbenicillin, bacitracin, and neomycin) were used in combinations to eliminate the contaminating bacteria from the E. caudatum culture in an attempt to develop an axenic culture of E. caudatum. These three antibiotics were chosen based on the results of Experiment 1 with respect to their low toxicity to E. caudatum and based on their complementary modes of antibiotic action. Three combinations of antibiotics were used: carbenicillin $(1 \mathrm{mg} / \mathrm{ml})$ plus bacitracin (0.05 $\mathrm{mg} / \mathrm{ml})$, carbenicillin plus neomycin $(0.1 \mathrm{mg} / \mathrm{ml})$, and carbenicillin plus bacitracin and neomycin. The antibiotic concentrations were selected based on their antibacterial activity and toxicity to the growth and morphology of E. caudatum. Soluble starch $(0.1 \%, \mathrm{w} / \mathrm{v})$, instead of the particulate protozoal feed, was added to SP medium as the substrate to support the growth of E. caudatum (because soluble starch is a better substrate than the particulate protozoal feed and the presence of the antibiotics prevents bacterial overgrowth on starch).

External growth factors were tested for their ability to support the growth of E. caudatum. The tested growth factors included fetal bovine serum $(1 \%, \mathrm{v} / \mathrm{v})$, stigmasterol $(1 \mu \mathrm{g} / \mathrm{ml})$, hemin $(0.767 \mu \mathrm{M})$, and bovine serum albumin $(0.005 \%, \mathrm{w} / \mathrm{v})$, all of which have been used in developing axenic cultures of ciliate protozoa by other researchers (Yamin, 1978; Wagener and Pfennig, 1987; Schousboe et al., 1992; Mori et al., 2011). All growth factors were added at the concentrations recommended in the above studies or at concentrations slightly modified based on a preliminary study. Cultures receiving no growth factors were included as a control. The cultures were incubated at $39^{\circ} \mathrm{C}$, and subsamples were collected at 0,24 , and $48 \mathrm{~h}$. Following serial dilutions in the anaerobic Simplex buffer, $0.1 \mathrm{ml}$ of each dilution was plated onto tryptic soy agar (TSA) plates prepared in an anaerobic chamber (Coy Laboratory Products Inc., USA) filled a gas mixture of $85 \% \mathrm{~N}_{2}, 10 \% \mathrm{H}_{2}$, and $5 \% \mathrm{CO}_{2}$. After anaerobic incubation for $2-3$ days at $39^{\circ} \mathrm{C}$ in the anaerobic chamber, bacterial colony forming units (CFU) were counted on each plate. E. caudatum cells in the subsamples were counted under a microscope as described in Experiment 1.

The three antibiotics used in Experiment 2 failed to eliminate the contaminating bacteria from the E. caudatum culture, so we tested another four antibiotics: ampicillin, carbenicillin, streptomycin, and oxytetracycline, all of which have been used in establishing axenic cultures of other ciliates. Briefly, a combination of ampicillin $(1.0 \mathrm{mg} / \mathrm{ml})$, streptomycin $(0.2$ $\mathrm{mg} / \mathrm{ml})$, carbenicillin $(1 \mathrm{mg} / \mathrm{ml})$, and oxytetracycline $(0.2 \mathrm{mg} / \mathrm{ml})$ was added to the cultures of E. caudatum. After incubation at $39^{\circ} \mathrm{C}$ for 3 days, the E. caudatum cells were counted under a microscope, while the elimination of the contaminating bacteria was confirmed by plating on TSA plates as described above. The temporarily axenic E. caudatum culture (based on confirmation of no CFU on the TSA plates) was washed once with SP medium to remove residual antibiotics and then transferred to sterile SP medium containing the protozoal feed that had been autoclaved in sealed tubes containing $\mathrm{CO}_{2}$. Cell suspensions of live bacteria (both individual and mixed) of the E. caudatum culture were tested for their ability to sustain the growth of the temporary axenic E. caudatum culture. Briefly, an actively growing E. caudatum culture that had not been treated with any antibiotic was filtered through a $10-\mu \mathrm{m}$ filter membrane as described above. The filtrate containing only the prokaryotes was centrifuged at $4^{\circ} \mathrm{C}$ to pellet the bacterial (and possibly archaeal) cells. After washing once in the anaerobic Simplex buffer, the cells of the mixed prokaryotes were resuspended in anaerobic SP medium (in the same volume of the filtrate, referred to as mixed bacteria). The E. caudatum cells retained on the filter membrane were recovered and washed thrice using sterile anaerobic Simplex buffer as described above. The washed $E$. caudatum cells were lysed using low-speed bead-beating $(2,400$ oscillations $/ \mathrm{min}$ ) for $45 \mathrm{~s}$ using sterile zirconia beads $(0.3 \mathrm{~g}$ of 0.1 $\mathrm{mm}$ and $0.1 \mathrm{~g}$ of $0.5 \mathrm{~mm}$; Biospec Products, Bartlesville, OK), and the lysate was serially diluted in anaerobic Simplex buffer and plated on TSA plates to isolate bacteria associated with the $E$. caudatum cells. After incubation anaerobically at $39^{\circ} \mathrm{C}$ for $48 \mathrm{~h}$, 
colonies that were well-separated and with distinctively different colony morphologies were inoculated into tryptic soy broth medium and incubated anaerobically at $39^{\circ} \mathrm{C}$ overnight. The cells from each bacterial isolate were harvested by centrifugation at room temperature, washed once in anaerobic Simplex buffer, and resuspended in SP medium (in the same volume of the original culture, referred to as individual bacterial isolates). Cell suspensions of nine individual bacterial isolates were prepared. Cell suspensions ( $1 \mathrm{ml}$ each) of the individual bacterial isolates, combinations of three of the nine bacteria, and the mixed bacteria were fed individually to the temporarily axenic E. caudatum culture daily. The control received no live bacteria.

\section{Statistical Analysis}

All the cultures of E. caudatum, both antibiotics-treated and the control, were grown in three replicates. The E. caudatum counts in the antibiotics-treated cultures were expressed as \% of that of the control culture that received no antibiotics, and culture OD (as an estimate of bacterial concentration) was subjected to two-way ANOVA using SAS 9.3 (SAS Institute, Cary, NC, USA). Orthogonal polynomial contrasts were used to determine linear or quadratic changes of protozoal cell counts by increasing concentrations of each antibiotic. Correlation between protozoal cell counts and OD of associated prokaryotes was examined using Pearson's correlation coefficient. Significant difference was declared at $P \leq 0.05$.

\section{RESULTS}

\section{Experiment 1. Growth Inhibition of E. caudatum and Its Associated Prokaryotes by Antibiotics}

All the antibiotic treatments significantly lowered the cell counts of E. caudatum except several of the antibiotics at the low concentrations, and the inhibition was aggravated at the later hours of the incubation (Table 3). Except for ampicillin, all the antibiotics exhibited a significantly linear dose-dependent inhibition of the growth of E. caudatum at 48 and $72 \mathrm{~h}$ incubation (Table 3). In the $72 \mathrm{~h} \mathrm{E}$. caudatum cultures containing 0.5 and $1 \mathrm{mg} / \mathrm{ml}$ of ampicillin, very few or no moving E. caudatum cells were seen under the microscope, but unexpectedly $2 \mathrm{mg} / \mathrm{m}$ ampicillin only lowered E. caudatum count by $>54 \%$. By the end of the $72 \mathrm{~h}$ incubation, protozoal cell counts did not differ between the control and the E. caudatum cultures receiving 0.1 or $0.5 \mathrm{mg} / \mathrm{ml}$ of streptomycin, $0.1 \mathrm{mg} / \mathrm{ml}$ of carbenicillin, or $0.1 \mathrm{mg} / \mathrm{ml}$ of neomycin even though these antibiotic-treated cultures had lower OD. Chloramphenicol exhibited the strongest inhibition of E. caudatum growth among the tested antibiotics, resulting in almost no live E. caudatum cells after $48 \mathrm{~h}$ incubation at all the tested concentrations.

All the antibiotics (except bacitracin) at the tested concentrations also significantly lowered the culture OD, which was used as an indicator of cell concentration of the prokaryotes in the E. caudatum cultures (Figure S1). Different antibiotics lowered OD to different extent, and greater OD inhibition was seen for all the antibiotics except bacitracin. For streptomycin (at 0.1 and $2 \mathrm{mg} / \mathrm{ml}$ only), carbenicillin, tetracycline, neomycin (at 0.1 and $0.3 \mathrm{mg} / \mathrm{ml}$ only), Normocin ${ }^{\mathrm{TM}}$, bacitracin (at 0.1 and $1 \mathrm{mg} / \mathrm{ml}$ only), and chloramphenicol, prolonged incubation did not result in further OD decrease. Overall, the OD of the cultures receiving ampicillin increased $(P=0.003)$ significantly over time, while that of the other antibiotic-treated cultures did not. Except for streptomycin, all the tested antibiotics resulted in a correlation between the cell counts of E. caudatum and the OD (Table 4).

SEM showed that both unwashed and washed E. caudatum cells of the control culture had almost no prokaryotic microbes attached to their surface (Figure 1). No apparent damage to the extracellular morphology or structure was noted after the filtration or washing steps, suggesting that the filtration and washing procedures did not result in visible morphological damage to the E. caudatum cells. When examined using TEM, very few intact prokaryotic cells were visible in the cytoplasm of the cells of the washed E. caudatum cultures that did not receive any antibiotic (Figure 2). Dividing intracellular prokaryotic cells were observed inside vacuoles surrounded by a membrane (Figures 2B,C), whereas others appeared partially degraded (Figure 2D). No intracellular prokaryotic cell was visible on the TEM micrographs of the E. caudatum cells treated with carbenicillin or Normocin $^{\mathrm{TM}}$, but one or less was seen on each section of the E. caudatum cells in the control culture (Table S1). Compared to the E. caudatum cells of the control culture, the antibiotics-treated E. caudatum cells appeared to have fewer dividing intracellular prokaryotes (Table S1).

All the antibiotics-treated E. caudatum cells showed alteration or destruction of extracellular morphology as revealed on SEM micrographs (Figure 3), but it was impossible to quantify such changes. As revealed on SEM micrographs, ampicillin (Figure 3A), and chloramphenicol (Figure 3H) resulted in disrupted cell surface structures of the E. caudatum cells, with bulging and loss of longitudinal striation on the cell surface. Streptomycin (Figure 3B), tetracycline (Figure 3D), and Normocin $^{\mathrm{TM}}$ (Figure 3G) also resulted in some distortion in the cuticle including swollen or shrunken pellicle structure. The ciliary zone was rather normal of the streptomycin-, carbenicillin-, neomycin-, and bacitracin-treated E. caudatum cells, whereas the other antibiotics totally destructed the ciliary zone. Bacitracin-treated E. caudatum cells had more surfaceattached prokaryotic microbial cells (both rod-shaped and coccus cells in company with high culture OD) than those of the control and the other treatments.

The intracellular structure of the E. caudatum cells was examined using TEM. Only the cells collected from the E. caudatum cultures treated with carbenicillin and Normocin ${ }^{\mathrm{TM}}$ were subjected to TEM. The E. caudatum cells treated by these two antibiotics were chosen because carbenicillin was one of the least toxic antibiotics (Figure 3, Table 3), and Normocin ${ }^{\mathrm{TM}}$ is commonly used in preventing mammalian cell cultures from bacterial contamination or decontaminating mammalian cell cultures and thus can be potentially used in developing axenic E. caudatum cultures. The E. caudatum cells from the control culture exhibited a clear distinction between the dense chromatin and granular nucleoli in both the MAC and MIC (Figure 4A), whereas all the E. caudatum cells in the cultures treated with either antibiotic lost such distinction in both the MIC and MAC 


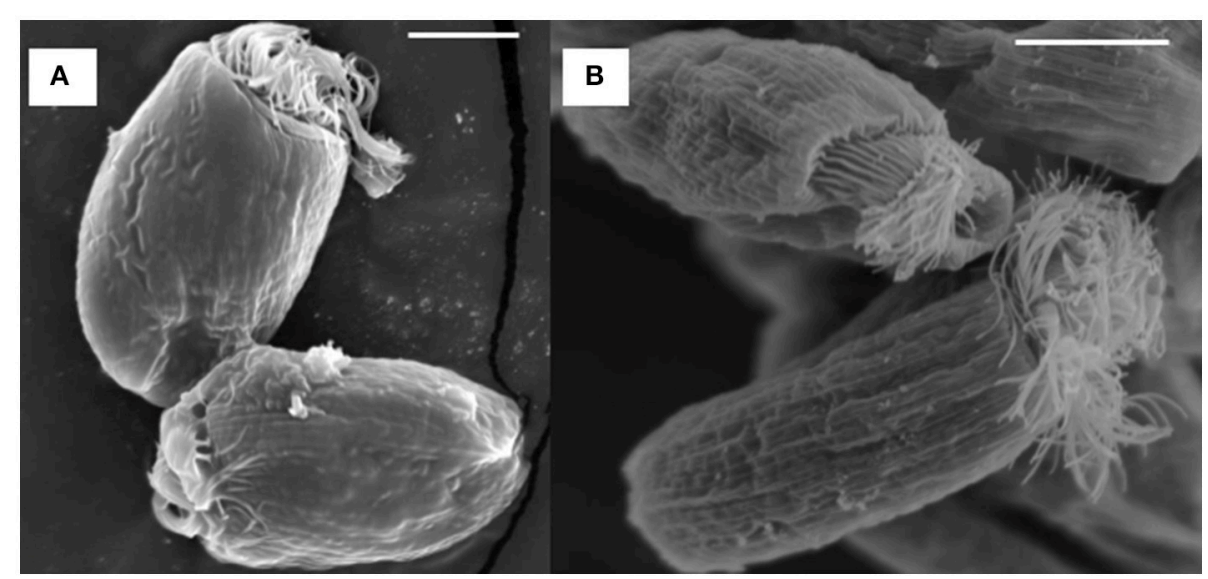

FIGURE 1 | Scanning electron micrograph of $E$. caudatum cells maintained in the in vitro cultures before (A) and after (B) filtration and washing. The in vitro cultures did not receive any antibiotics. The scale bars $=10 \mu \mathrm{m}$.

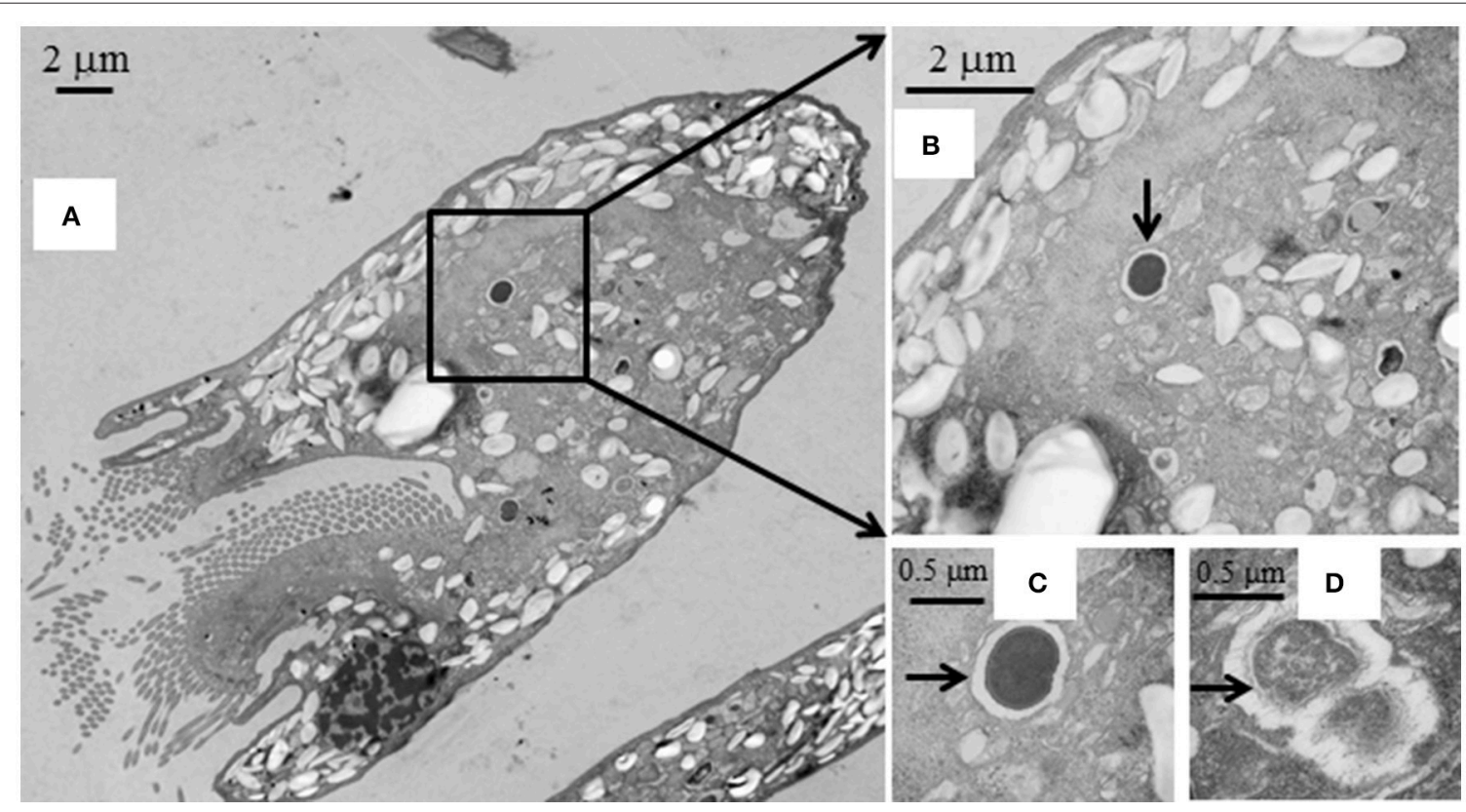

FIGURE 2 | Transmission electron micrographs of E. caudatum cells that were not exposed to antibiotics. (A), longitudinal section; (B), a dividing microbial cell in the endoplasm (pointed by the arrow); (C), amplified view of the dividing microbe; and (D), a microbial cell being degraded/digested.

(Figures 4B,C). No apparent difference in the degree of the damage, which was not possible to quantify, was noted between $24 \mathrm{~h}$ and for $48 \mathrm{~h}$ of exposure to these two antibiotics. Compared to the control, the exposure to these two antibiotics increased the number and the size of polysaccharide granules in all the observed cells (Table S1), which were mainly visualized in the ectoplasm as electron lucent bodies (Figure 5). When the areas of the largest 5 granules in 5 longitudinally sectioned E. caudatum cells were measured, carbenicillin and Normocin ${ }^{\mathrm{TM}}$ significantly $(P<0.05)$ increased the granule sizes compared to the control (Figure 6). Iodine staining of the E. caudatum cells showed that these granules are glycogen granules. In addition, sloughing of the glycocalyx covering the external membrane was noted, and electro-dense epiplasm, which consists of two underlying layers with occasional granularity underneath cell membrane, was not distinct inside the antibiotics treated cells (Figure 7). However, it was not possible to quantify the degree of such changes.

\section{Experiment 2: Preparation of a Temporarily Axenic Culture of E. caudatum and Its Growth Recovery}

Based on the results of Experiment 1, three of the antibiotics (carbenicillin, bacitracin, and neomycin) and their two- and 


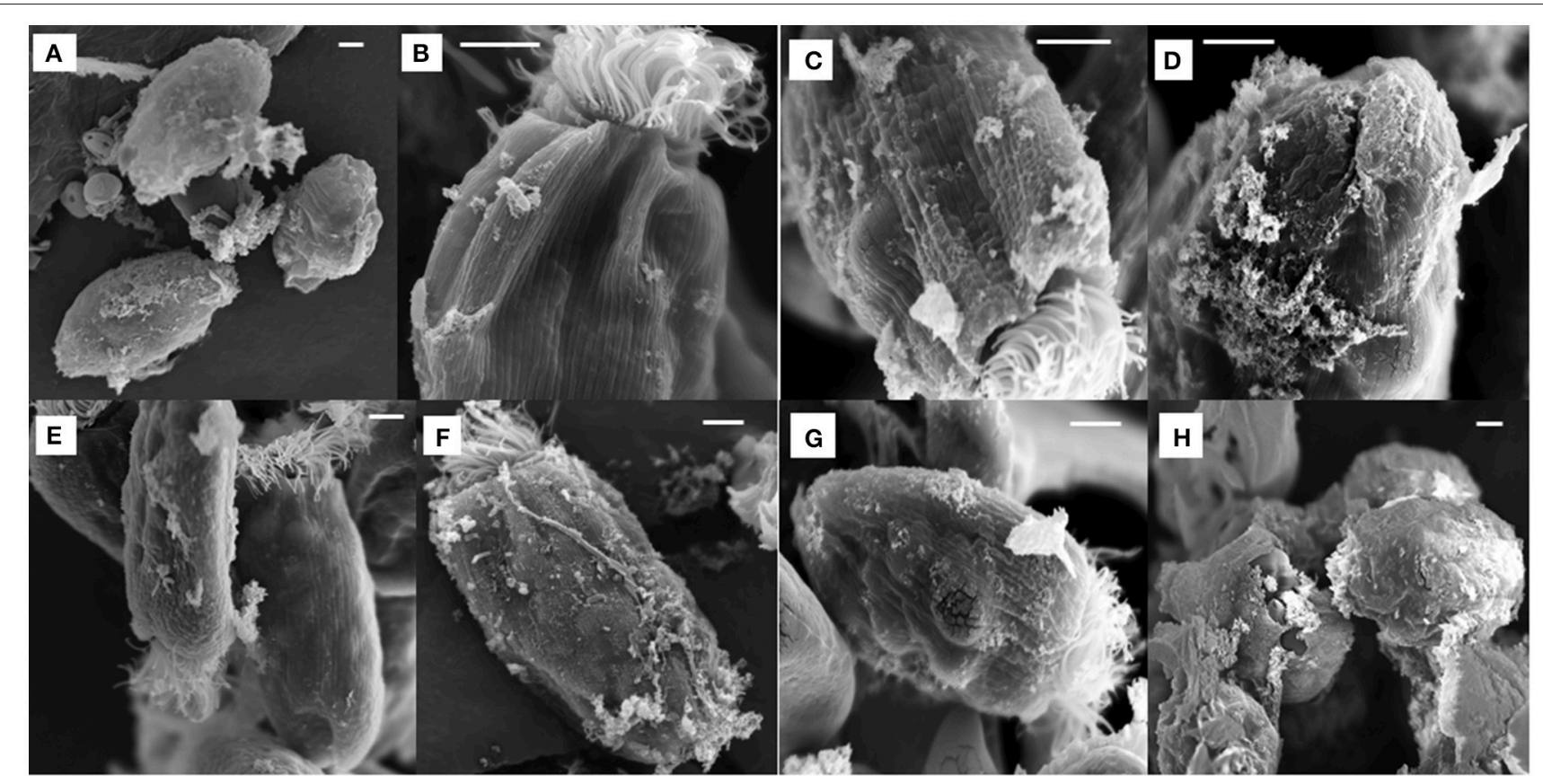

FIGURE 3 | Scanning electron micrograph of E. caudatum cells in the antibiotics-treated cultures (after $48 \mathrm{~h}$ incubation). The micrograph of non-treated E. caudatum cells was shown in Figure 1. (A) ampicillin $(0.5 \mathrm{mg} / \mathrm{ml}) ;$ (B) streptomycin $(2 \mathrm{mg} / \mathrm{ml})$; (C) carbenicillin $(2 \mathrm{mg} / \mathrm{ml})$; (D) tetracycline $(0.3 \mathrm{mg} / \mathrm{ml}) ;(\mathbf{E})$, neomycin (1 mg/ml); (F) bacitracin (1 mg/ml); (G) Normocin ${ }^{\mathrm{TM}}(0.5 \mathrm{mg} / \mathrm{ml})$; and (H) chloramphenicol $(0.005 \mathrm{mg} / \mathrm{ml})$. The scale bars $=5 \mu \mathrm{m}$.

three-way concentrations were used to generate an axenic culture of E. caudatum. These three antibiotics were chosen for three reasons. First, carbenicillin was one of the most effective antibiotics in inhibiting the prokaryotes in the $E$. caudatum culture (Figure S1) and the least toxic to the E. caudatum cells in terms of cellular surface damage (Figure 3) and decrease in viability (Table 3). Second, bacitracin is less toxic than the other antibiotics as revealed by the clear cytoplasmic matrix and a lack of increased accumulation of intracellular polysaccharide granules under a light microscope (data not shown). Third, neomycin has a broad spectrum of antibiotic activity by directly inhibiting protein synthesis in bacteria. The growth of E. caudatum was inhibited in the presence of the three antibiotics, alone and in combinations, irrespective the presence of the growth factors (Figure 8). The cultures containing growth factors only had numerically more E. caudatum cells than the control that received no growth factors. The two- and threeway combinations of the three antibiotics decreased E. caudatum growth after $48 \mathrm{~h}$ incubation. All the treatments still had living bacteria after $48 \mathrm{~h}$ incubation: $10-30 \mathrm{CFU} / \mathrm{ml}$ of cultures that received the growth factors and $110-250 \mathrm{CFU} / \mathrm{ml}$ of cultures that received no growth factors.

In another attempt to establish an axenic E. caudatum culture, we tested a combination of ampicillin $(1.0 \mathrm{mg} / \mathrm{ml})$, carbenicillin $(1.0 \mathrm{mg} / \mathrm{ml})$, streptomycin $(0.2 \mathrm{mg} / \mathrm{ml})$, and oxytetracycline $(0.2$ $\mathrm{mg} / \mathrm{ml}$ ). After 3 days incubation, no bacterial colonies were seen on TSA plates that had been plated with the antibiotictreated E. caudatum culture directly (without any dilution) and anaerobically incubated for 3 days. After transfer to fresh SP medium containing no antibiotics, however, protozoal cell count gradually declined and became undetectable by light microscopy within 4-5 days (Figure S2). Daily addition of fetal bovine serum, stigmasterol, hemin, and bovine serum albumin, both alone and combinations thereof, to the temporarily axenic E. caudatum culture failed to stop the protozoal cell count decline (Figure S2). When each of the nine individual bacteria isolated from the original E. caudatum culture was added to the temporarily axenic E. caudatum culture, either individually or in combinations of three thereof, the gradual E. caudatum cell count decrease was slowed but continued (Figure 9). When the mixed bacteria separated from the E. caudatum culture was added daily, the $E$. caudatum cell count did not decrease by day 1 and then gradually recovered and increased by day 4 , whereas in the control that received no live bacterial feeding, E. caudatum cells disappeared by day 3 (Figure 9 ).

\section{DISCUSSION}

Axenic cultures of protozoa are needed to fully understand their metabolism and physiology. Repeated attempts to establish an axenic culture of rumen anaerobic ciliate protozoa at best achieved a temporarily axenic culture that could only be maintained for a very short period (Coleman, 1962; Hino and Kametaka, 1977; Bonhomme et al., 1982a,b). In the present study, we evaluated the inhibition of $E$. caudatum growth by eight antibiotics (including three that inhibit cell wall synthesis and five that inhibits protein synthesis) that have been previously 


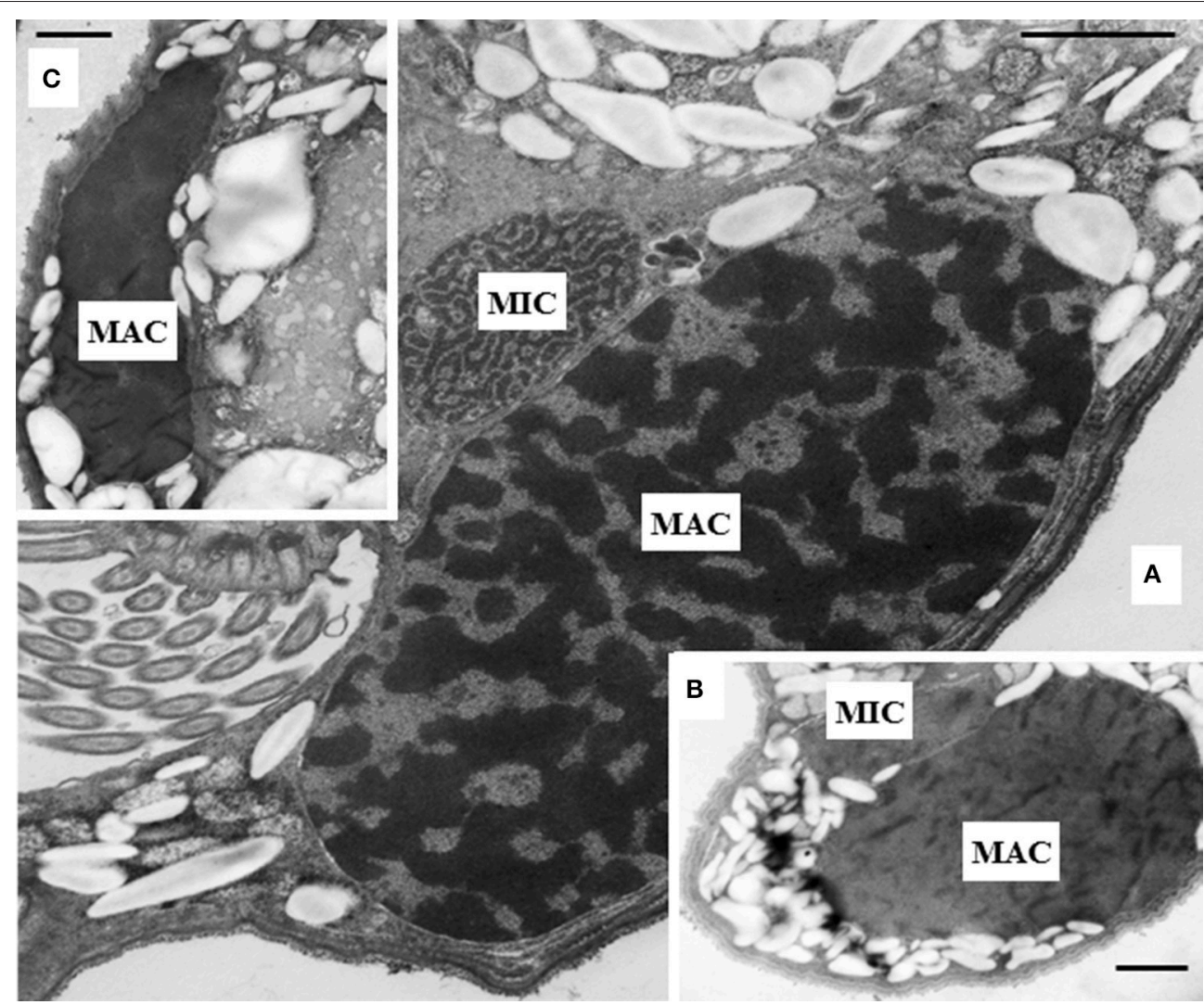

FIGURE 4 | (A) Micronucleus (MIC) and macronucleus (MAC) in the ectoplasm of an E. caudatum cell that was not treated with any antibiotics. Both chromatin (electron dense dark areas) and granular nucleoli (gray areas) were visible in both the MIC and MAC. MAC and increased number of glycogen granules upon treatment with $1 \mathrm{mg} / \mathrm{ml}$ carbenicillin (B) and $0.1 \mathrm{mg} / \mathrm{ml} \mathrm{Normocin}^{\mathrm{TM}}$ (C) for $48 \mathrm{~h}$. The scale bars $=1 \mu \mathrm{m}$.

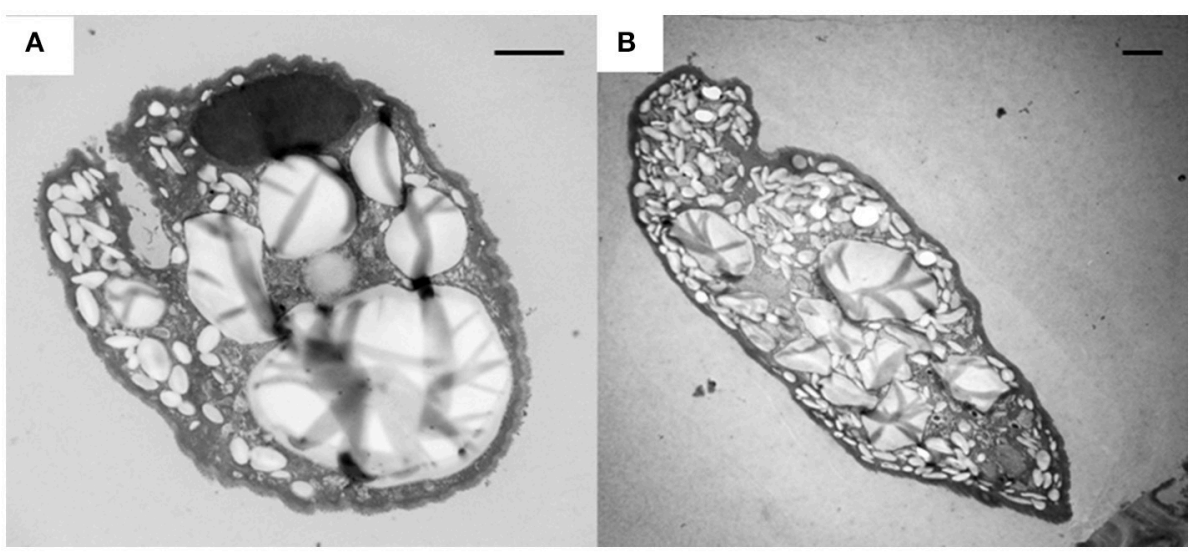

FIGURE 5 | Accumulation of glycogen granules (electron lucent bodies) in E. caudatum cells treated with carbenicillin (1 mg/ml) for $24 \mathrm{~h}$ (A) and Normocin TM (0.1 $\mathrm{mg} / \mathrm{ml}$ ) for $48 \mathrm{~h}$ (B). The scale bars $=2 \mu \mathrm{m}$.

used in establishing axenic cultures of other ciliate species. Our results showed that all the antibiotics inhibited the growth of $E$. caudatum even at or below the concentrations used in developing axenic cultures of species of Paramecium and T. thermophila (Table 2). Except for ampicillin at $48 \mathrm{~h}$, all the antibiotics exhibited inhibition to E. caudatum in a linear manner. However, different linearity was apparent for most of the antibiotics over different doses. Even though a comparison of toxicity at the same concentration is logical, varying concentrations of different antibiotics were tested based on literature information. 
Even at concentrations lower than that of the other antibiotics, chloramphenicol caused extensive destruction of the cell surface of E. caudatum cells. This is consistent with its high toxicity (Feder, 1986), and this antibiotic should be excluded from future efforts to generate axenic cultures of ruminal protozoa.

Effects of antibiotics on ruminal ciliate cell structures have not been investigated, although growth inhibition was observed in experiments to establish axenic cultures (Dehority, 2008). In the present study, we examined the surface structures of $E$. caudatum cells treated with eight antibiotics. Chloramphenicol appeared to cause the worse damage, followed by ampicillin. The degree of damage to the cell surface structure is consistent with the extremely low cell counts of E. caudatum $(0.5 \mathrm{mg} / \mathrm{ml}$ ampicillin and $0.005 \mathrm{mg} / \mathrm{ml}$ chloramphenicol at $48 \mathrm{~h}$ ). We further examined the intracellular structures of the E. caudatum cells treated with carbenicillin, an inhibitor of peptidoglycan synthesis, which did not show profound damage to the cell surface of E. caudatum. We also examined Normocin ${ }^{\mathrm{TM}}$, which is a combination of two antibiotics that inhibits bacterial protein and DNA synthesis and one fungicide that has been used in preventing mammalian cell cultures from bacterial and fungal contamination. As shown by TEM, these two antibiotics damaged the structure of chromatin. It is not known how these antibiotics cause structural damage to the E. caudatum chromatin, but such damage might contribute to their antibiotics toxicity.

Disruption of membranous structure and accumulation of intracellular granular polysaccharides are believed signs of dying ruminal ciliates (Zeitz et al., 2011). Such morphological changes were seen in the antibiotics-treated E. caudatum cells. The outermost part of the E. caudatum cells is the glycocalyx (Ergen et al., 2000). Antibiotics-treated cells had loosened appearance of filamentous glycocalyx (Figure 7), which to our knowledge has not been reported from dying protozoa cell. Damaged glycocalyx may affect association with ectosymbionts in ruminal ciliates (Ng et al., 2016) and/or transport of soluble nutrients in unicellular parasitic protozoa (Naderer and McConville, 2008). The TEM showed few intracellular prokaryotic cells inside of the E. caudatum cells. One study detected intracellular prokaryotes as endosymbionts through probe hybridization (Lloyd et al., 1996), but some other authors disputed the presence of intracellular prokaryotes including methanogens as true endosymbionts (Coleman and Hall, 1972; Valle et al., 2015). Because of the lack of hydrogenosomes, E. caudatum cells probably do not have methanogens as true endosymbionts. More definitive methodologies, including the use of starved $E$. caudatum cells that have depleted engulfed preys, are needed to determine the presence or absence of true endosymbiotic prokaryotes.

All aerobic eukaryotes contain mitochondria, while most anaerobic eukaryotes contain hydrogenosomes or related mitosomes, both of which have evolved from alphaProteobacteria (Rotte et al., 2000). Consistent with a previous report (Hackstein et al., 2008) and revealed by the TEM, E. caudatum cells contain no hydrogenosomes, but they do contain mitosomes. Although evolved from mitochondria, hydrogenosomes, and mitosomes differ in functions.

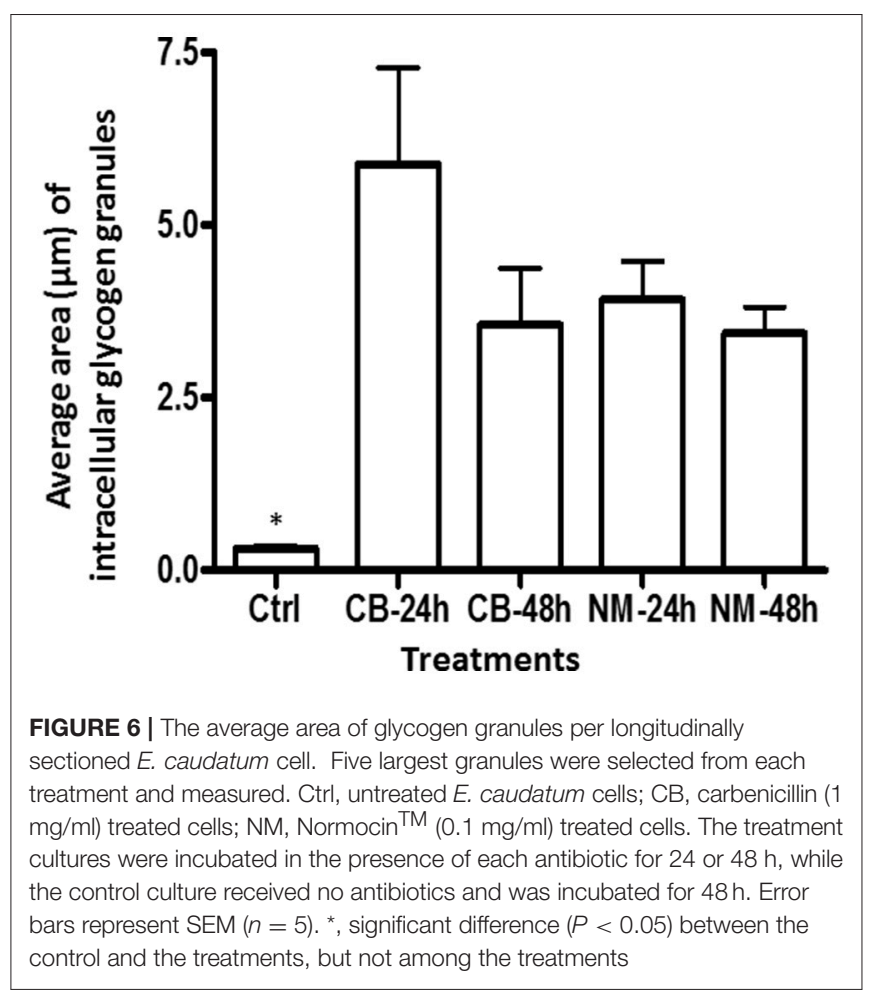

Hydrogenosomes produce $\mathrm{H}_{2}$ and ATP, but mitosomes do not. Mitosomes are involved in Fe-S cluster formation (Hackstein and Tielens, 2010). In E. caudatum cells, both fermentation and production of $\mathrm{H}_{2}$ and ATP probably take pace in the cytosol. Some of the side effects of many antibiotics are attributed to the residual structural similarity of these two organelles to bacteria (Cohen, 2010; Barnhill et al., 2012; Cohen and Saneto, 2012). Even though mitosomes are not involved in energy production, antibiotics can still inhibit E. caudatum by inhibiting $\mathrm{Fe}-\mathrm{S}$ cluster formation in its mitosomes. In addition, many antibiotics, such as aminoglycoside antibiotics (Rizzi and Hirose, 2007), penicillin (Matsuda et al., 2002), and chloramphenicol (Holt et al., 1997), induce apoptotic cell death of mammalian cells, and mitochondria are believed to mediate apoptosis in mammalian cells (Xiong et al., 2014) and aerobic protists (Chose et al., 2003). However, it is not known if mitosomes are also involved in apoptosis. Toxicity to mitosomes and apoptosis, mediated by either mitosomes or another cellular structure of E. caudatum, may be further investigated as possible reasons of antibiotic toxicity to E. caudatum. The mobility inhibition by chloramphenicol observed in $T$. thermophila (Wu et al., 1996) may not be excluded as a type of toxicity, at least for chloramphenicol. Aminoglycosides at $5 \mathrm{mM}$ (or $2.9 \mathrm{mg} / \mathrm{ml}$ for streptomycin), a concentration that is higher than those used in the present study, was not noxious for the growth of Tetrahymena spp. (Eustice and Wilhelm, 1984), suggesting that E. caudatum might be more sensitive to the toxicity of antibiotics than Tetrahymena spp.

The E. caudatum cells treated with carbenicillin or Normocin $^{\mathrm{TM}}$ showed increased accumulation of glycogen granules. This is consistent with the chemical analysis that 


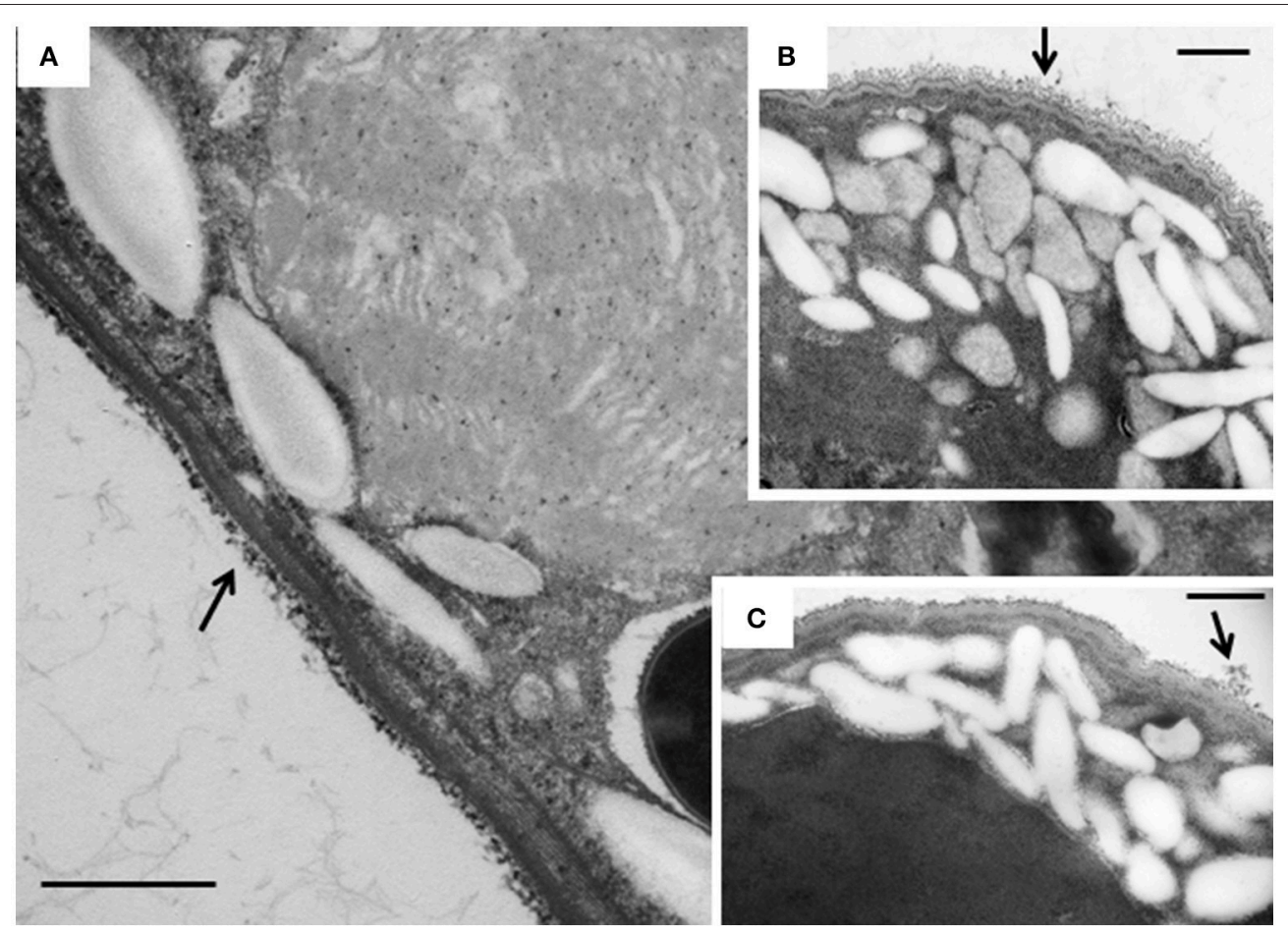

FIGURE 7 | TEM micrographs of the cortex of E. caudatum cells. (A) untreated E. caudatum cells; (B) carbenicillin (1 $\mathrm{mg} / \mathrm{ml}$, for 48 h) treated cells; (C) Normocin ${ }^{\mathrm{TM}}$ $(0.1 \mathrm{mg} / \mathrm{ml}, 24 \mathrm{~h}$ ) treated cells. External filamentous glycocalyx (arrows) covering the cortical layers of $E$. caudatum cells showed morphological disparity between antibiotics-treated and untreated cells. The scale bars $=500 \mathrm{~nm}$.
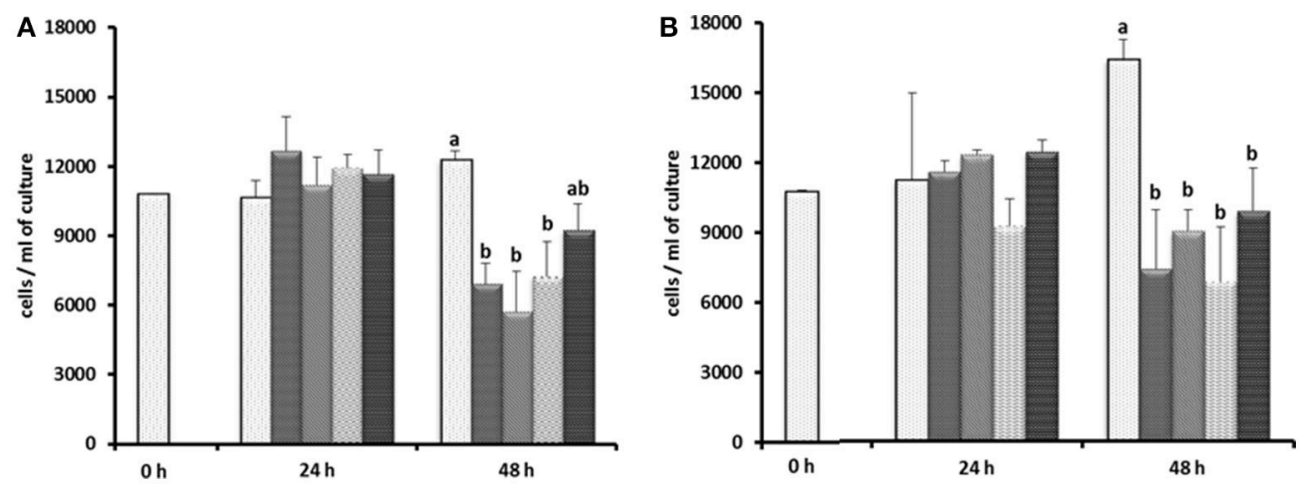

FIGURE 8 | Effect of carbenicillin alone and its combination with bacitracin and neomycin and growth factors on E. caudatum cell counts. antibiotics; = carbenicillin (1 mg/ml); = combination of carbenicillin and bacitracin $(0.05 \mathrm{mg} / \mathrm{ml}) ;$ $(0.1 \mathrm{mg} / \mathrm{ml})$; 蔡 = combination of carbenicillin, bacitracin, and neomycin. (A), no addition of growth factors; (B), addition of $1 \%$ [v/v] fetal bovine serum, $1 \mu \mathrm{g} / \mathrm{ml}$ $[\mathrm{w} / \mathrm{v}]$ stigmasterol, $0.767 \mu \mathrm{M}$ heminm and $0.005 \%[\mathrm{w} / \mathrm{v}]$ bovine serum albumin. Erros bars SEM $(n=3)$.

showed glycogen is the major carbohydrate reserve in $E$. caudatum (Denton et al., 2015). Repression of glycogen phosphorylase via undetermined mechanism by antibiotics might be one reason of accumulated glycogen granules in the endoplasm of antibiotics-treated E. caudatum cells. Inhibited glycogen utilization may also increase accumulation of glycogen granules and contribute to the observed antibiotic toxicity either by lowering ATP availability or by physical obstruction to normal cellular processes. Upon removal of endosymbionts, the resultant aposymbiotic Euplotes harpa and $E$. aediculatus also increased accumulation of intracellular glycogen granules (Vannini et al., 2003). It was suggested that the endosymbionts of these two Euplotes species produce some metabolites that are needed for glycogenolysis. The 


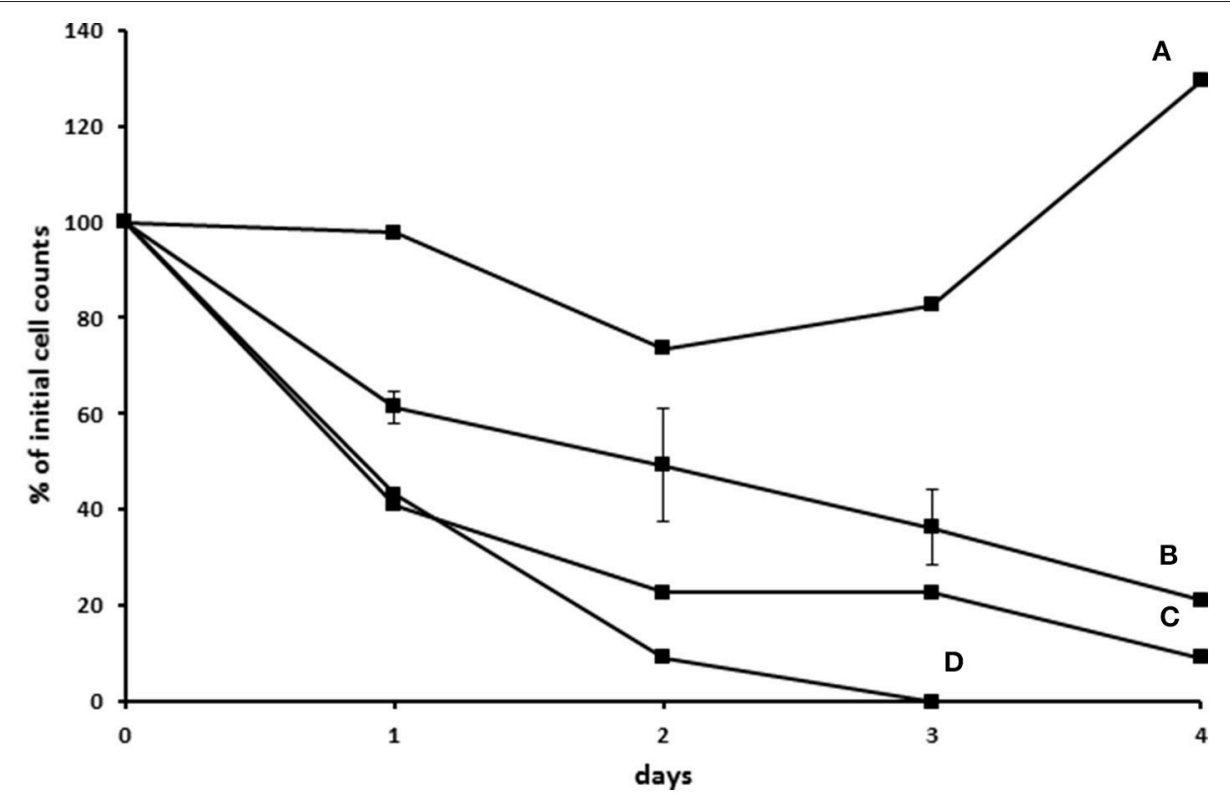

FIGURE 9 | Effect of adding live bacteria (isolated from the E. caudatum culture) to the growth of temporarily axenic cultures of E. caudatum. (A) daily feeding with the mixed bacterial fraction from the culture of $E$. caudatum (not treated with any antibiotics); (B) daily feeding with single bacterial isolates from a washed non-antibiotic treated E. caudatum culture (average of feeding three bacterial isolates); (C) daily feeding of a combination of three bacteria isolated from a washed non-antibiotic treated $E$. caudatum culture; (D) control without daily feeding of any live bacteria.

same authors also suggested that glycogenolysis provides the energy for Euplotes species to grow (Vannini et al., 2007). The results of Vannini et al. and ours indicate that glycogen is an important energy source and the antibiotic treatment might have deprived E. caudatum of the ability to produce energy for growth.

Combinations of antibiotics are the primary strategy to develop axenic cultures of ciliates, including attempts to generate axenic cultures of ruminal protozoa (Table 2). $\beta$-Lactam antibiotics that inhibit bacterial peptidoglycan synthesis and antibiotics that inhibit prokaryotic protein synthesis are most commonly used in combinations to obtain axenic cultures of unicellular eukaryotes (Allen and Nerad, 1978; CassidyHanley, 2012). A number of non-ruminal ciliates have been successfully cultured and maintained as axenic cultures, but no attempt has succeeded in establishing any axenic ruminal protozoal cultures that can be maintained for repeated use in laboratory research. Although less toxic, carbenicillin, bacitracin, and neomycin failed to eliminate all the bacteria present in the original $E$. caudatum culture at the tested concentrations. The combination of ampicillin $(1.0 \mathrm{mg} / \mathrm{ml})$, carbenicillin $(1.0$ $\mathrm{mg} / \mathrm{ml})$, streptomycin $(0.2 \mathrm{mg} / \mathrm{ml})$, and oxytetracycline $(0.2$ $\mathrm{mg} / \mathrm{ml}$ ) successfully eliminated the associated bacteria resulting in a temporarily axenic E. caudatum culture lasting for about 3 days. We tested most of the growth factors that have been used in growing axenic cultures of other protozoal species (Allen and Nerad, 1978; Wagener and Pfennig, 1987; Christensen et al., 1996; Mori et al., 2011), both individually or in combinations, but none of them could help the survival of the temporarily axenic E. caudatum. Intriguingly, the bacterial fraction reversed the decline of cell counts in the temporary E. caudatum culture, whereas the bacteria isolated from the washed E. caudatum cells, either individually or in threeway combinations, did not. These observations suggest that certain live bacteria allow E. caudatum to repair antibioticsinduced cellular damage and are essential for its long-term survival. The E. caudatum cell counts and the $\mathrm{OD}$ in the antibiotics-treated E. caudatum cultures also appeared to be correlated.

Collectively, these results suggest that E. caudatum requires live bacteria of certain species for its survival and growth. It is speculative, but the constant and reliable presence of some ruminal bacteria might have led to the loss of some essential capability to synthesize essential metabolites by $E$. caudatum. This is consistent with the proposed nutritional and metabolic dependence of the ruminal ciliates on their living prey (Fondevila and Dehority, 2001). Antibiotics probably cause both direct cytotoxicity to E. caudatum and indirect inhibition by killing the bacteria that are needed for its long-term survival. Cultures of E. caudatum with one or more bacteria, instead of axenic cultures, may be developed for future research of its physiology and metabolism. The bacterial fraction of the E. caudatum culture can be serially diluted, and each dilution can be tested for its ability to "rescue" the temporarily axenic E. caudatum culture. The required bacteria by E. caudatum can then be isolated from the dilution that can rescue the temporarily axenic E. caudatum culture. Genomic studies of E. caudatum may help determine the metabolic potential and physiological requirement and thus help establish axenic cultures of E. caudatum. 


\section{CONCLUSION}

E. caudatum has few endo- or ecto-symbionts. Antibiotics commonly used to develop axenic cultures of protozoa and to decontaminate mammalian cell cultures inhibited the growth of E. caudatum, in an antibiotics- and concentrationdependent manner. Damage to the cell surface and nuclei and increased accumulation of intracellular glycogen granules were evident morphological changes upon antibiotic treatments. A temporarily axenic culture of E. caudatum was prepared using combinations of antibiotics, but it could not be maintained. Live bacteria are probably required for the survival and growth of E. caudatum. The results of this study can help future research in understanding the relationship between ruminal protozoa and their prokaryotic partners. This study can also be helpful for future effort to develop new strategies to establish monoxenic or polyxenic cultures of E. caudatum and other species of ruminal protozoa.

\section{REFERENCES}

Abràmoff, M. D., Magalhães, P. J., and Ram, S. J. (2004). Image processing with ImageJ. Biophotonics Int. 11, 36-42.

Allen, S. L., and Nerad, T. A. (1978). Method for the simultaneous establishment of many axenic cultures of Paramecium. J. Protozool. 25, 134-139. doi: 10.1111/j.1550-7408.1978.tb03884.x

Barnhill, A. E., Brewer, M. T., and Carlson, S. A. (2012). Adverse effects of antimicrobials via predictable or idiosyncratic inhibition of host mitochondrial components. Antimicrob. Agents Chemother. 56, 4046-4051. doi: 10.1128/AAC.00678-12

Biagini, G. A., Mcintyre, P. S., Finlay, B. J., and Lloyd, D. (1998). Carbohydrate and amino acid fermentation in the free-living primitive protozoon Hexamita sp. Appl. Environ. Microbiol. 64, 203-207.

Bonhomme, A. (1990). Rumen ciliates: their metabolism and relationships with bacteria and their hosts. Anim. Feed Sci. Technol. 30, 203-266. doi: 10.1016/0377-8401(90)90016-2

Bonhomme, A., Durand, M., Quintana, C., and Halpern, S. (1982a). Influence du cobalt et de la vitamine B12 sur la croissance et la survie des ciliés du rumen in vitro, en fonction de la population bactérienne. Reprod. Nutr. Dév. 22, 107-122. doi: 10.1051/rnd:19820109

Bonhomme, A., Fonty, G., and Senaud, J. (1982b). Attempt to obtain and maintain rumen entodiniomorph ciliates in axenic cultures. Ann. Microbiol. 133, 335-341.

Cassidy-Hanley, D. M. (2012). Tetrahymena in the laboratory: strain resources, methods for culture, maintenance, and storage. Methods Cell Biol. 109, 237-276. doi: 10.1016/B978-0-12-385967-9.00008-6

Cho, J. Y., Choi, J. S., Kong, I. S., Park, S. I., Kerr, R. G., and Hong, Y. K. (2002). A procedure for axenic isolation of the marine microalga Isochrysis galbana from heavily contaminated mass cultures. J. Appl. Phycol. 14, 385-390. doi: 10.1023/A:1022199332224

Chose, O., Sarde, C. O., Noël, C., Gerbod, D., Jimenez, J. C., Brenner, C., et al. (2003). Cell death in protists without mitochondria. Ann. N. Y. Acad. Sci. 1010, 121-125 doi: 10.1196/annals.1299.021

Christensen, S. T., Kemp, K., Quie, H., and Rasmussen, L. (1996). Cell death, survival and proliferation in Tetrahymena thermophila. Effects of insulin, sodium nitroprusside, 8-bromocyclic GMP, NG-methyl-L-arginine and methylene blue. Cell Biol. Int. 20, 653-666. doi: 10.1006/cbir.1996.0087

Cohen, B. H. (2010). Pharmacologic effects on mitochondrial function. Dev. Disabil. Res. Rev. 16, 189-199. doi: 10.1002/ddrr.106

Cohen, B. H., and Saneto, R. P. (2012). Mitochondrial translational inhibitors in the pharmacopeia. Biochim. Biophys. Acta 1819, 1067-1074. doi: 10.1016/j.bbagrm.2012.02.023

\section{AUTHOR CONTRIBUTIONS}

TP and ZY conceived and designed the experiment. TP executed the experiment and wrote the manuscript. TM contributed to the experiment. JF and ZY revised the manuscript.

\section{ACKNOWLEDGMENTS}

This material is based upon work that is partially supported by the National Institute of Food and Agriculture, U.S. Department of Agriculture, under award number 2012-67015-19437. We thank Dr. Luis E. Moraes for his help with the statistical analysis of the data.

\section{SUPPLEMENTARY MATERIAL}

The Supplementary Material for this article can be found online at: http://journal.frontiersin.org/article/10.3389/fmicb. 2017.01189/full\#supplementary-material

Coleman, G. S. (1962). The preparation and survival of almost bacteriafree suspensions of Entodinium caudatum. J. Gen. Microbiol. 28, 271-281. doi: 10.1099/00221287-28-2-271

Coleman, G., and Hall, F. (1972). Fine structural studies on digestion of bacterial species in the rumen ciliate, Entodinium caudatum. Tissue Cell 4, 37-48. doi: 10.1016/S0040-8166(72)80004-1

Dehority, B. A. (1993). Laboratory Manual for Classification and Morphology of Rumen Ciliate Protozoa. Boca Raton, FL: CRC Press, Inc.

Dehority, B. A. (1998). Generation times of Epidinium caudatum and Entodinium caudatum, determined in vitro by transferring at various time intervals. J. Anim. Sci. 76, 1189-1196. doi: 10.2527/1998.7641189x

Dehority, B. A. (2008). Improved in vitro procedure for maintaining stock cultures of three genera of rumen protozoa. J. Anim. Sci. 86, 1395-1401. doi: $10.2527 /$ jas.2007-0238

Dehority, B. A. (2010). Physiological characteristics of several rumen protozoa grown in vitro with observations on within and among species variation. Eur. J. Protistol. 46, 271-279. doi: 10.1016/j.ejop.2010.05.002

Denton, B. L., Diese, L. E., Firkins, J. L., and Hackmann, T. J. (2015). Accumulation of reserve carbohydrate by rumen protozoa and bacteria in competition for glucose. Appl. Environ. Microbiol. 81, 1832-1838. doi: 10.1128/AEM.03736-14

Ergen, G., Göçmen, B., and Falakali, B. (2000). Ultrastructure of the cortex of the rumen ciliate Ophryoscolex purkynjei Stein, 1858 (Entodiniomorphida: Ophryoscolecidae). Turk. J. Zool. 24, 385-390.

Erlandsen, S. L., Bemrick, W. J., Wells, C. L., Feely, D. E., Knudson, L., Campbell, S. R., et al. (1990). Axenic culture and characterization of Giardia ardeae from the great blue heron (Ardea herodias). J. Parasitol. 76, 717-724. doi: $10.2307 / 3282988$

Eustice, D. C., and Wilhelm, J. M. (1984). Fidelity of the eukaryotic codonanticodon interaction: interference by aminoglycoside antibiotics. Biochemistry 23, 1462-1467. doi: 10.1021/bi00302a019

Feder, H. Jr. (1986). Chloramphenicol: what we have learned in the last decade. South. Med. J. 79, 1129-1134. doi: 10.1097/00007611-198609000-00022

Firkins, J. L., Yu, Z., and Morrison, M. (2007). Ruminal nitrogen metabolism: perspectives for integration of microbiology and nutrition for dairy. J. Dairy Sci. 90(Suppl. 1), E1-E16. doi: 10.3168/jds.2006-518

Fondevila, M., and Dehority, B. A. (2001). Preliminary study on the requirements of Entodinium exiguum and E. caudatum for live or dead bacteria when cultured in vitro. Reprod. Nutr. Dev. 41, 41-46. doi: 10.1051/rnd:2001110

Foster, T. (1983). Plasmid-determined resistance to antimicrobial drugs and toxic metal ions in bacteria. Microbiol. Rev. 47, 361-409.

Gottlieb, D., and Shaw, P. (1967). Antibiotics, Vol. 1. (Berlin: Springer-Verlag).

Hackstein, J. H., De Graaf, R. M., Van Hellemond, J. J., and Tielens, A. G. (2008). "Hydrogenosomes of anaerobic ciliates," in Hydrogenosomes and Mitosomes: 
Mitochondria of Anaerobic Eukaryotes, ed J. Tachezy (Heidelberg: Springer), 97-112.

Hackstein, J. H., and Tielens, A. G. (2010). "Hydrogenosomes," in (Endo) Symbiotic Methanogenic Archaea, ed J. H. P. Hackstein (Heidelberg: Springer), 175-206.

Hino, T., and Kametaka, M. (1977). Gnotobiotic and axenic cultures of a rumen protozoon, Entodinium caudatum. J. Gen. Appl. Microbiol. 23, 37-48. doi: 10.2323 /jgam.23.37

Holt, D. E., Ryder, T. A., Fairbairn, A., Hurley, R., and Harvey, D. (1997). The myelotoxicity of chloramphenicol: in vitro and in vivo studies: I. In vitro effects on cells in culture. Hum. Exp. Toxicol. 16, 570-576. doi: $10.1177 / 096032719701601004$

Irbis, C., and Ushida, K. (2004). Detection of methanogens and proteobacteria from a single cell of rumen ciliate protozoa. J. Gen. Appl. Microbiol. 50, 203-212 doi: 10.2323 /jgam. 50.203

Lloyd, D., Williams, A. G., Amann, R., Hayes, A. J., Durrant, L., and Ralphs, J. R. (1996). Intracellular prokaryotes in rumen ciliate protozoa: detection by confocal laser scanning microscopy after in situ hybridization with fluorescent 16S rRNA probes. Eur. J. Protistol. 32, 523-531. doi: 10.1016/S0932-4739(96)80011-3

Lwoff, A. (1923). Sur la nutrition des infusoires. C. R. Acad. Sci. 176, 928-930.

Matsuda, T., Saito, H., Fukatsu, K., Han, I., Inoue, T., Furukawa, S., et al. (2002). Differences in neutrophil death among beta-lactam antibiotics after in vitro killing of bacteria. Shock 18, 69-74. doi: 10.1097/00024382-200207000-00013

Moazed, D., and Noller, H. F. (1987). Interaction of antibiotics with functional sites in 16 ribosomal RNA. Nature 327:389. doi: 10.1038/327389a0

Mori, K., Kashiwagi, A., and Yomo, T. (2011). Single-cell isolation and cloning of Tetrahymena thermophila cells with a fluorescence-activated cell sorter. J. Eukaryot. Microbiol. 58, 37-42. doi: 10.1111/j.1550-7408.2010.00517.x

Naderer, T., and McConville, M. J. (2008). The Leishmania-macrophage interaction: a metabolic perspective. Cell. Microbiol. 10, 301-308. doi: 10.1111/j.1462-5822.2007.01096.x

Newbold, C. J., De La Fuente, G., Belanche, A., Ramos-Morales, E., and Mcewan, N. (2015). The role of ciliate protozoa in the rumen. Front. Microbiol. 6:1313. doi: $10.3389 /$ fmicb. 2015.01313

Ng, F., Kittelmann, S., Patchett, M. L., Attwood, G. T., Janssen, P. H., Rakonjac, J., et al. (2016). An adhesin from hydrogen-utilizing rumen methanogen Methanobrevibacter ruminantium M1 binds a broad range of hydrogen-producing microorganisms. Environ. Microbiol. 18, 3010-3021. doi: 10.1111/1462-2920.13155

Nsabimana, E., Kišidayová, S., Macheboeuf, D., Newbold, C. J., and Jouany, J. P. (2003). Two-step freezing procedure for cryopreservation of rumen ciliates, an effective tool for creation of a frozen rumen protozoa bank. Appl. Environ. Microbiol. 69, 3826-3832. doi: 10.1128/AEM.69.7.3826-3832.2003

Ocampo, P. S., Lázár, V., Papp, B., Arnoldini, M., Abel Zur Wiesch, P., BusaFekete, R., et al. (2014). Antagonism between bacteriostatic and bactericidal antibiotics is prevalent. Antimicrob. Agents Chemother. 58, 4573-4582. doi: 10.1128/AAC.02463-14

Onodera, R., and Henderson, C. (1980). Growth factors of bacterial origin for the culture of the rumen oligotrich protozoon, Entodinium caudatum. J. Appl. Bacteriol. 48, 125-134 doi: 10.1111/j.1365-2672.1980.tb05214.x

Reynolds, E. (1963). The use of lead citrate at high $\mathrm{pH}$ as an experimental study. J. Cell Biol. 17, 208-212. doi: 10.1083/jcb.17.1.208

Rizzi, M. D., and Hirose, K. (2007). Aminoglycoside ototoxicity. Curr. Opin. Otolaryngol. Head Neck Surg. 15, 352-357. doi: 10.1097/MOO.0b013e3282ef772d

Rotte, C., Henze, K., Muller, M., and Martin, W. (2000). Origins of hydrogenosomes and mitochondria. Curr. Opin. Microbiol. 3, 481-486. doi: 10.1016/S1369-5274(00)00126-0

Schmidt, T. M. (2006). The maturing of microbial ecology. Int. Microbiol. 9, 217-223.

Schousboe, P., Christensen, S. T., Ghiladi, M., and Rasmussen, L. (1992). Porphyrin rings and phospholipids: stimulators of cloning efficiency in certain species of Tetrahymena. J. Protozool. 39, 343-345. doi: 10.1111/j.1550-7408.1992.tb01327.x

Soldo, A. T. (1963). Axenic culture of Paramecium-some observations on the growth behavior and nutritional requirements of a particle-bearing strain of Paramecium aurelia 299ג. Ann. N. Y. Acad. Sci. 108, 380-388. doi: 10.1111/j.1749-6632.1963.tb13392.x
Sylvester, J. T., Karnati, S. K., Yu, Z., Newbold, C. J., and Firkins, J. L. (2005). Evaluation of a real-time PCR assay quantifying the ruminal pool size and duodenal flow of protozoal nitrogen. J. Dairy Sci. 88, 2083-2095. doi: 10.3168/jds.S0022-0302(05)72885-X

Valle, E. R., Henderson, G., Janssen, P. H., Cox, F., Alexander, T. W., and Mcallister, T. A. (2015). Considerations in the use of fluorescence in situ hybridization (FISH) and confocal laser scanning microscopy to characterize rumen methanogens and define their spatial distributions. Can. J. Microbiol. 61, 417-428. doi: 10.1139/cjm-2014-0873

Van Bambeke, F., Michot, J.-M., and Tulkens, P. M. (2003). Antibiotic efflux pumps in eukaryotic cells: occurrence and impact on antibiotic cellular pharmacokinetics, pharmacodynamics and toxicodynamics. J. Antimicrob. Chemother. 51, 1067-1077. doi: 10.1093/jac/ dkg225

Vannini, C., Lucchesi, S., Rosati, G., Margulis, L., Hall, J., and Mcfall-Ngai, M. (2007). Polynucleobacter: symbiotic bacteria in ciliates compensate for a genetic disorder in glycogenolysis. Symbiosis 44, 85-91.

Vannini, C., Petroni, G., Schena, A., Verni, F., and Rosati, G. (2003). Wellestablished mutualistic associations between ciliates and prokaryotes might be more widespread and diversified than so far supposed. Eur. J. Protistol. 39, 481-485. doi: 10.1078/0932-4739-00024

Varadyova, Z., Kisidayova, S., Zelenak, I., and Siroka, P. (2001). Effect of antibiotics, 2-bromoethanesulfonic acid and pyromellitic diimide on methanogenesis in rumen ciliate cultures in vitro. Arch. Tierernahr. 54, 33-46. doi: 10.1080/17450390109381964

Wagener, S., and Pfennig, N. (1987). Monoxenic culture of the anaerobic ciliate Trimyema compressum Lackey. Arch. Microbiol. 149, 4-11. doi: 10.1007/BF00423128

Wilkens, S. L., and Maas, E. W. (2012). Development of a novel technique for axenic isolation and culture of thraustochytrids from New Zealand marine environments. J. Appl. Microbiol. 112, 346-352. doi: 10.1111/j.1365-2672.2011.05197.x

Williams, A. G. and Coleman, G. S. (1992). "Role of protozoa in the rumen," in The Rumen Protozoa (London: Springer-Verlag), 317-347.

Williams, A., and Yarlett, N. (1982). An improved technique for the isolation of holotrich protozoa from rumen contents by differential filtration with defined aperture textiles. J. Appl. Bacteriol. 52, 267-270. doi: 10.1111/j.1365-2672.1982.tb04849.x

Wu, C., Clift, P., Fry, C. H., and Henry, J. A. (1996). Membrane action of chloramphenicol measured by protozoan motility inhibition. Arch. Toxicol. 70, 850-853. doi: $10.1007 / \mathrm{s} 002040050349$

Xiong, S., Mu, T., Wang, G., and Jiang, X. (2014). Mitochondriamediated apoptosis in mammals. Protein Cell 5, 737-749. doi: 10.1007/s13238-014-0089-1

Yamada, K., Kamagata, Y., and Nakamura, K. (1997). The effect of endosymbiotic methanogens on the growth and metabolic profile of the anaerobic freeliving ciliate Trimyema compressum. FEMS Microbiol. Lett. 149, 129-132. doi: 10.1111/j.1574-6968.1997.tb10319.x

Yamin, M. A. (1978). Axenic cultivation of the cellulolytic flagellate Trichomitopsis termopsidis (Cleveland) from the termite Zootermopsis. J. Protozool. 25, 535-538. doi: 10.1111/j.1550-7408.1978.tb04181.x

Zeitz, J. O., Meile, L., Michalowski, T., Kreuzer, M., and Soliva, C. R. (2011). Suitability of different media for in vitro cultivation of the ruminal protozoa species Entodinium caudatum, Eudiplodinium maggii, and Epidinium ecaudatum. Eur. J. Protistol. 47, 314-317. doi: 10.1016/j.ejop.2011. 04.004

Conflict of Interest Statement: The authors declare that the research was conducted in the absence of any commercial or financial relationships that could be construed as a potential conflict of interest.

Copyright $\odot 2017$ Park, Meulia, Firkins and Yu. This is an open-access article distributed under the terms of the Creative Commons Attribution License (CC $B Y)$. The use, distribution or reproduction in other forums is permitted, provided the original author(s) or licensor are credited and that the original publication in this journal is cited, in accordance with accepted academic practice. No use, distribution or reproduction is permitted which does not comply with these terms. 